MARIA BEATRIZ DE MIRANDA TOLEDO

Nulidades das disposições testamentárias

Dissertação de Mestrado

Orientadora Professora Titular Giselda Maria Fernandes Novaes Hironaka

UNIVERSIDADE DE SÃO PAULO

FACULDADE DE DIREITO

São Paulo - SP

2020 

MARIA BEATRIZ DE MIRANDA TOLEDO

\section{Nulidades das disposições testamentárias}

Dissertação apresentada a Banca Examinadora do Programa de Pós-Graduação em Direito da Faculdade de Direito da Universidade de São Paulo, como exigência parcial para obtenção do título de Mestre em Direito na área de concentração Direito Civil, sob a orientação da Professora Titular Giselda Maria Fernandes Novaes Hironaka.

UNIVERSIDADE DE SÃO PAULO

FACULDADE DE DIREITO

São Paulo - SP 
Catalogação da Publicação

Serviço de Biblioteca e Documentação

Faculdade de Direito da Universidade de São Paulo

Toledo, Maria Beatriz de Miranda

Nulidades das disposições testamentárias ; Maria Beatriz de Miranda Toledo; orientadora Giselda

Maria Fernandes Novaes Hironaka -- São Paulo, 2020.

221

Dissertação (Mestrado - Programa de Pós-Graduação em Direito Civil) - Faculdade de Direito, Universidade de São Paulo, 2020.

1. Testamento. 2. Disposições testamentárias. 3. Nulidade. I. Hironaka, Giselda Maria Fernandes Novaes, orient. II. Título. 


\section{SUMÁRIO}

INTRODUÇ̃̃̃O

1. Vontade E MORTe: AS Feições do Testamento NA DOgMática do NEgócio

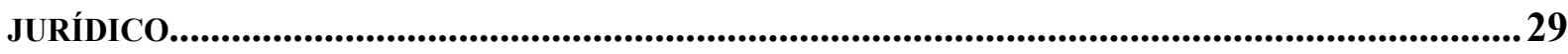

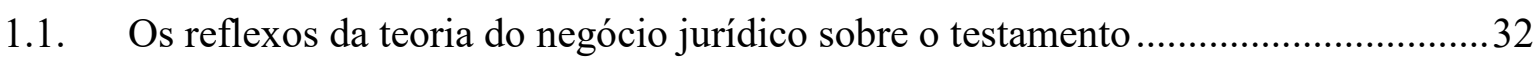

1.2. As características do testamento no quadro geral dos negócios jurídicos .................41

1.3. A filtragem de validade do conteúdo do testamento como limite à liberdade de testar 48

1.4. A necessária distinção entre a nulidade do conteúdo do testamento e a valoração moral das escolhas do testador

2. NULIDADES PREVISTAS NO REGIME GERAL DO NEGÓCIO JURÍDICO QUE SE APLICAM AO TESTAMENTO . .61

2.1. Nulidade da disposição testamentária cujo objeto é ilícito, impossível, indeterminado ou indeterminável .62

2.2. Nulidade da disposição testamentária que impõe condição ilícita ou impossível ....64

2.2.1. Nulidade da condição contrária à lei, à ordem pública ou aos bons costumes. 69

2.2.1.1. As condições de o beneficiário se casar ou de não se casar . .73

2.2.1.2. A condição de o beneficiário se divorciar ou se separar ................................76

2.2.1.3. A condição de o beneficiário permanecer viúvo ..........................................77

2.2.1.4. A condição de o beneficiário se afastar de familiares ...................................78

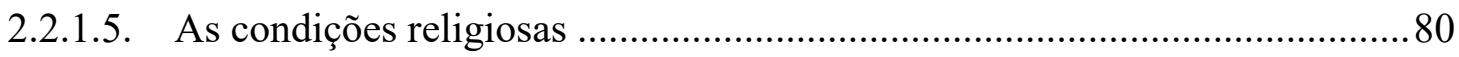

2.2.1.6. A inadequada busca por solução a priori...................................................... 81

2.2.2. Nulidade da condição impossível ou contraditória ........................................... 82

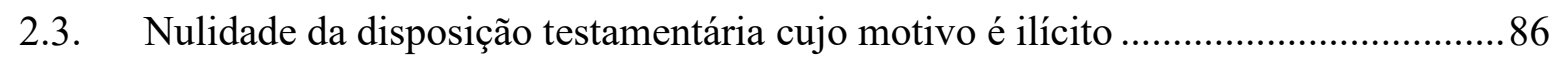

2.4. Nulidade do encargo ilícito e impossível como motivo determinante da disposição testamentária .90

2.5. Nulidade de disposições extrapatrimoniais ......................................................93

3. O PROBLEMA DAS DISPOSIÇÕES TESTAMENTÁRIAS DISCRIMINATÓRIAS OU QUE

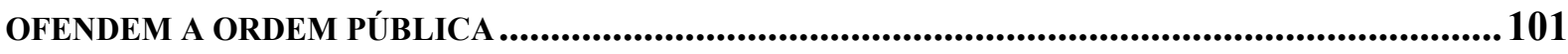

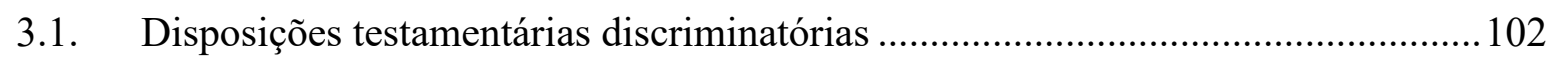

3.1.1. O problema da antidiscriminação como princípio do Direito Civil brasileiro104 
3.1.2. O debate sobre as disposições testamentárias discriminatórias na experiência estrangeira .

3.1.3. O debate sobre as disposições testamentárias discriminatórias no direito brasileiro 120

3.2. Disposições testamentárias que ofendem a ordem pública

4. NULIDADES ESPECÍFICAS DAS DISPOSIÇÕES TESTAMENTÁRIAS.

4.1. A condição captatória (art. 1.900, I, do Código Civil).

4.2. Disposição em benefício de pessoa incerta (art. 1.900, II e III, do Código Civil). 139

4.3. Fixação do valor do legado ao arbítrio de terceiro (art. 1.900, IV, do Código Civil) 145

4.4. Disposição em benefício de pessoas que não podem receber por testamento (art. 1.900, V, do Código Civil)......

4.5. Conversão dos bens da legítima em bens de outra espécie (art. 1.848, $\S 1^{\circ}$, do Código Civil) 156

4.6. Disposição testamentária que institui fideicomisso além do segundo grau (art. 1.959 do Código Civil).

4.7. A ausência da justa causa para as cláusulas de inalienabilidade, impenhorabilidade e incomunicabilidade sobre os bens da legítima (art. 1.848 do Código Civil) 165

4.8. A disposição testamentária que deserda herdeiro sem fundamento ou com fundamento estranho às hipóteses dos arts. 1.962 e 1.963 do Código Civil 170

\section{ASPECTOS RELEVANTES SOBRE A IMPUGNAÇÃO DAS DISPOSIÇÕES TESTAMENTÁRIAS}

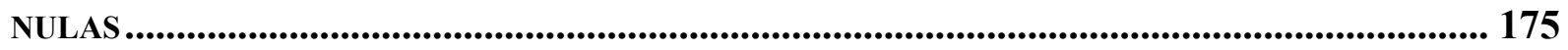

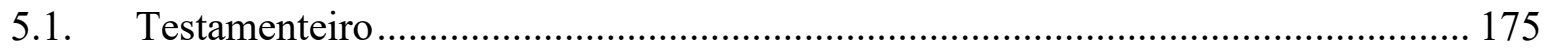

5.2. A ação cabível para declarar a nulidade de disposição testamentária.................... 178

5.2. O prazo decadencial para propositura dessa ação ............................................... 183

5.3. O problema da validade da cláusula de não impugnar o testamento ..................... 187

5.4. O debate sobre a cláusula compromissória testamentária.................................... 194

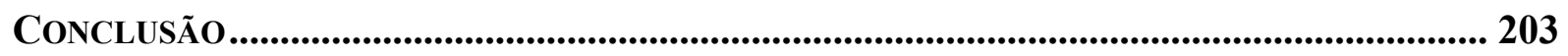

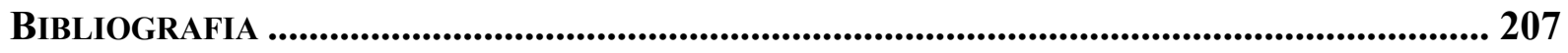


À minha mãe, por tudo o que foi À Virna Máximo, por tantas vezes estar Ao Vitor Butruce, por acreditar no que posso ser 



\section{AGRADECIMENTOS}

Engana-se quem presume que a morte é um fim em si. Da morte nascemos, imensamente - disse Vinicius de Moraes. Renascemos a cada fim com novas e imensas perspectivas. Temse, ainda, a chance de contar com percursos nada solitários. Assim foi, para a minha sorte, a jornada que acompanhou essas linhas do início ao fim.

À Professora Giselda Maria Fernandes Novaes Hironaka agradeço sobretudo por receber este projeto nas Arcadas. O carinho e a firmeza com os quais conduziu a orientação deste trabalho e suas contribuições valiosas me permitiram uma experiência transformadora.

Aos Professores e colegas do Programa de Pós-Graduação da FDUSP, especialmente ao Bruno Marques e Felipe Russomanno, agradeço pelos debates curiosos (e nem sempre jurídicos). À Cláudia Stein, parceira de orientação, pela solidariedade e pelo afeto. Ao amigo Pedro Kurbhi, em memória, pela paciência com a qual tantas vezes me ouviu sobre este trabalho e por tantos conselhos - você faz falta.

À Gabriela Cavalheiro sou grata pela contribuição tão doce quanto talentosa com alguns dos temas dessa pesquisa: muito obrigada.

Ao BMA Advogados agradeço pela experiência que me proporciona e pelos vínculos que me viabiliza cultivar. Ao Plínio Barbosa sou grata pelas oportunidades de trabalhar com casos tão complexos e curiosos; ao Chico Müssnich, por me apresentar os campos dinâmicos da arbitragem esportiva; e ao Pedro Costa, tanto pela confiança quanto por plantar a semente da advocacia contenciosa. Aos queridos integrantes do Diversidade agradeço os exemplos que inspiram e a esperança que multiplicam. Aos amigos da biblioteca, pela ajuda e pelo carinho constantes - e também à biblioteca, pelas preciosidades sem as quais páginas faltariam neste trabalho. Aos amigos da Baiacool, pela injeção de ânimo diária, sem vocês certamente não teria a mesma graça. À Raysa Vital Brazil agradeço pela imensa torcida, pelo companheirismo e por colecionar comigo várias figurinhas ao longo dos últimos anos.

À Equipe VAJ agradeço por todo apoio nos afastamentos que me permitiram escrever estas linhas: à Fernanda Szyszka, pelo brilhantismo ímpar; à Ana Leticia Siqueira, pela convivência leve e tão prestativa; e à Giovana Cunha, recém-chegada ao time para nos encher de fôlego. Ao Caio Marotti, com quem dividi prazos e ansiedades, não necessariamente nessa ordem, agradeço muitíssimo pela parceria de sempre. 
Meu sincero agradecimento a quem tanto admiro: Rebeca Garcia, Nathalie Gazzaneo e Karen Mentzingen. A amizade de vocês faz com que as escolhas tenham mais sentido. Devo a vocês risadas intermináveis e sábios conselhos - à Nathalie sou grata também por alguns textos que, de Massachusetts, chegaram às minhas mãos imediata e carinhosamente.

Minha gratidão não é novidade ao Vitor Butruce, a quem devo tanto nos últimos anos. Ao Vitor sou grata por me apresentar a Priscilla - e à Priscilla, por tanto carinho. Ao Vitor também devo o empurrão que me fez tentar o ingresso no mestrado do Largo São Francisco. O seu incentivo, nem sempre sutil, e a sua generosidade inesgotável me trouxeram aqui. No Vitor enxergo a determinação em me fazer maior - tamanha, que só o afeto permite.

À Luciana Ernanny Legey agradeço por me relembrar de analisar os significados, tão simbólicos, e de não deixar vazio (mudo) o espaço do Outro.

À minha família, em Maceió, em Recife, no Rio ou em São Paulo, agradeço pelo constante apoio. Em especial: aos meus avós, ao meu pai, à Rita e à minha irmã-fera, Anita, pela motivação que me inspiram e pela força que me transmitem. Aos tios Flávio e Adriana e às primas Lara e Luiza, pela acolhida de sempre. À Jó e à Nice, pelo amor sem medida. À Maria Paula Toledo, pela amizade desde que somos nós e por ler sofridas minutas deste trabalho. À Maria Fernanda e à Renata Toledo, por tanta companhia. À Laura Toledo: muitíssimo obrigada por dividir e ouvir as aflições dos últimos anos e por me fazer ver tanto amor em São Paulo.

Às velhas amigas de infância, Aline Emílio e Dandara Mendonça, por continuarem a ser aconchego.

Ao meu irmão, João Victor, agradeço as inúmeras escaladas para compartilhar comigo as joias das bibliotecas da Universidade de Coimbra; e por compartilhar também a minha saudade diária. Obrigada por tanto amor.

À Virna Maximo, minha irmã na vida, não tenho palavras para agradecer. Virna é estrutura: sem ela este trabalho, como tantos outros eventos nos últimos tempos, não seria possível. Seu suporte e sua compaixão são de outro planeta. Sua vontade de ajudar, mesmo nas leituras ainda áridas das primeiras versões, me impressiona. Sou muitíssimo grata por caminhar perto de você.

Muito obrigada a todos. 
"Sei que, quando chegar a minha hora, entrarei no nada, dissolver-me-ei em átomos. [...] Dedicamos demasiado tempo a conjecturar o que há para além da vida, e demasiado pouco a interrogarmo-nos sobre o que está a acontecer na própria vida".

José Saramago 



\section{RESUMO}

TOLEDO, Maria Beatriz de Miranda. Nulidades das disposições testamentárias. 2020. 221 fls. Dissertação (Mestrado) - Faculdade de Direito, Universidade de São Paulo, São Paulo, 2020.

Esta dissertação se concentra no problema do alcance do controle jurisdicional de mérito das escolhas do testador por meio do filtro da nulidade das disposições testamentárias. O estudo parte da percepção de que legislação, doutrina e jurisprudência passaram a flexibilizar dois vetores históricos da sucessão testamentária: as exigências de formalismo do testamento e de capacidade do testador. A atenção se volta, então, para o conteúdo do testamento. O Código Civil alocou a filtragem de conteúdo no plano da validade dos negócios jurídicos, em especial quanto à sua nulidade. Por isso, o Capítulo 1 parte da compreensão do testamento enquanto negócio jurídico, suas peculiaridades, bem como os impactos da filtragem de validade do testamento no princípio da liberdade de testar. Destaca-se também, na largada, a distinção entre nulidade e valoração moral. O Capítulo 2 trata das nulidades previstas na Parte Geral do Código Civil, particularmente os arts. 123, 137 e 166 do Código Civil, que também se aplicam às disposições testamentárias. Na sequência, o Capítulo 3 passa analisar o problema da validade das disposições discriminatórias ou contrárias à ordem pública, inspirando-se na jurisprudência brasileira recente e em casos decididos em outras jurisdições. O Capítulo 4 pontua as hipóteses específicas de nulidade das disposições testamentárias, na forma dos arts. 1.900, 1.848, 1.959 e 1.964 do Código Civil. Ao final, o Capítulo 5 traz algumas questões processuais que repercutem na investigação da nulidade de disposição testamentária, com especial destaque para o papel do testamenteiro na defesa da validade do instrumento, o prazo decadencial para se postular a nulidade, a viabilidade da cláusula de não impugnar a disposição testamentária e da cláusula compromissória no testamento. Investiga-se, portanto, ao longo desta dissertação, as situações em que o exame de mérito das escolhas do testador é juridicamente adequado.

Palavras-chave: Testamento. Disposições testamentárias. Conteúdo do testamento. Nulidade. Invalidade. Anulação. Liberdade de testar. 



\begin{abstract}
TOLEDO, Maria Beatriz de Miranda. Nullity of the testamentary provisions. 2020. $221 \mathrm{p}$. Dissertation (Master) - Faculdade de Direito, Universidade de São Paulo, São Paulo, 2020.

This study focuses on the problem of the extent of jurisdictional control of the merits of the testator's choices through the nullity filter of testamentary dispositions. The study starts from the perception that legislation, legal scholars and court precedents began to assign more flexibility to two historical vectors of testamentary succession: the requirements of testament formalism and the legal capacity of the testator. Attention then turns to the content of the will. The Civil Code has allocated content filtering in terms of the validity of legal transaction, in particular with regards to its nullity. Therefore, Chapter 1 starts with understanding the will as a legal transaction, its peculiarities, as well as the impacts of filtering the validity of the will on the principle of freedom of testation. Also noteworthy is the distinction between nullity and moral valuation. Chapter 2 deals with the nullities provided for in the General Part of the Civil Code, particularly articles 123, 137 and 166 of the Civil Code, which also apply to testamentary provisions. Subsequently, Chapter 3 analyzes the problem of the validity of discriminatory provisions and provisions contrary to public order, drawing on recent Brazilian court precedents and precedents rendered in others jurisdictions. Chapter 4 points out the specific hypotheses of the nullity of the testamentary dispositions, in the form of arts. 1,900,1,848, 1,959 and 1,964 of the Civil Code. In the end, Chapter 5 brings some procedural questions that affect the investigation of the nullity of the testament, especially the role of the executor in defending the validity of the instrument, the period to postulate the nullity, the viability of the testamentary provision that prohibits the beneficiary to challenge the testament and the arbitration clause in the will. Therefore, this study investigates the situations in which the merit examination of the testator's choices is legally appropriate.
\end{abstract}

Keywords: Testament. Will. Testamentary provisions. Will content. Validity. Nullity. Void. Testamentary freedom. 



\section{LISTA DE SIGLAS E ABREVIATURAS}

AC - Apelação Cível

AI - Agravo de Instrumento

AREsp - Agravo em Recurso Especial

art. - artigo

arts. - artigos

CC - Câmara Cível

CDPriv. - Câmara de Direito Privado

CJF - Conselho da Justiça Federal

Des. - Desembargador

ed. - edição

j. - julgado em

Min. - Ministro

nºu n. - número

p. ou pp. - página(s)

Rel. - relator

REsp - Recurso Especial

RE - Recurso Extraordinário

STF - Supremo Tribunal Federal

STJ - Superior Tribunal de Justiça

T. - Turma

TJMG - Tribunal de Justiça do Estado de Minas Gerais

TJPE - Tribunal de Justiça do Estado de Pernambuco

TJPR - Tribunal de Justiça do Estado do Paraná

TJRJ - Tribunal de Justiça do Estado do Rio de Janeiro

TJRS - Tribunal de Justiça do Estado do Rio Grande do Sul

TJSC - Tribunal de Justiça do Estado de Santa Catarina

TJSP - Tribunal de Justiça do Estado de São Paulo

v. - volume

v. m. - votação por maioria

v. u. - votação unânime 



\section{INTRODUÇ̃̃o}

"Morte somos e morte vivemos. Mortos nascemos, mortos passamos; mortos já, entramos na Morte. Tudo quanto vive, vive porque muda; muda porque passa; e porque passa, morre. Tudo quanto vive perpetuamente se torna outra coisa, constantemente se nega, se furta à vida. A vida é pois um intervalo, um nexo, uma relação, mas uma relação entre o que passou, o que passará, intervalo morto entre a Morte e a Morte"1.

Curioso episódio (provavelmente no plano das lendas) se atribui a Alfred Nobel. Em abril de 1888, um jornal francês publicou obituário de impacto: "o comerciante da morte está morto", em referência ao descobridor da dinamite, "que ficou rico encontrando formas de matar mais pessoas de maneira mais rápida do que nunca"2. Entretanto, Alfred Nobel estava vivo - o falecido Nobel era seu irmão, Ludvig - e leu seu próprio obituário. A lenda prossegue, então, para dizer que o lapso do jornal francês não passou despercebido pelo inventor - que, a partir da descoberta de como poderiam receber sua morte, elaborou, em 1895, testamento em que deixou parte de sua fortuna para financiar prêmios anuais para "aqueles que, durante o ano anterior, conferi[ssem] o maior benefício à humanidade": o prêmio Nobel ${ }^{3}$.

A partir da narrativa de Nobel - que, para fins acadêmicos presume-se, ao menos, verossímil -, vê-se que o testamento é um ato jurídico em que o sujeito encara a si próprio, percebe seus valores (patrimoniais e existenciais) e define a imagem sobre si que deseja projetar ao futuro ${ }^{4}$.

Diante disso, há de se perguntar: cabe a um terceiro - um julgador - interferir nas escolhas do testador ${ }^{5}$ e fazer uma filtragem de mérito do conteúdo do testamento?

\footnotetext{
${ }^{1}$ Fernando Pessoa, sob o pseudônimo de Bernardo Soares, no texto "Intervalo".

${ }^{2}$ A referência da passagem está em: SNEDDON, Karen J. The Will as Personal Narrative (2013). Elder Law Journal, Vol. 20, 2013. Disponível em: <https://ssrn.com/abstract=2354609>. Acessado em 12.12.2019. Para mais sobre a credibilidade da narrativa confira-se: ANDREWS, Evan. Did a Premature Obituary Inspire the Nobel Prize? History Stories. Publicado em 9.12.2016. Disponível em: < https://www.history.com/news/did-a-prematureobituary-inspire-the-nobel-prize>. Acessado em 12.12.2019

3 Pode-se ler o testamento de Albert Nobel em: <https://www.nobelprize.org/alfred-nobel/full-text-of-alfrednobels-will-2/>. Acessado em 16.12.2019.

${ }^{4}$ Nas palavras de Karen J. Sneddon, "o testamento oferece a oportunidade de representar um sentido dos valores pessoais que são fundamentais para a narrativa pessoal" No original: "the will affords the opportunity to represent a sense of the personal values that are fundamental to the personal narrative" (SNEDDON, Karen J. The Will as Personal Narrative (2013). Elder Law Journal, Vol. 20, 2013. Disponível em: <https://ssrn.com/abstract=2354609>. Acessado em 12.12.2019).

${ }^{5}$ Neste trabalho, por "testador", genericamente, entenda-se sempre "testadora ou testador"; por "testamenteiro", "testamenteiro ou testamenteira"; e nos demais casos em que se indique genericamente o gênero masculino.
} 
Um exemplo ajuda a ilustrar a pergunta.

Imagine-se que Roberto, um jovem empresário, investe em tecnologia e acumula vultoso patrimônio com pouca idade. Solteiro, sem descendentes ou ascendentes, fica parte do tempo recluso em sua mansão. Dispensa o convívio com a irmã, Iza, com quem não se comunica há anos. Quando está em férias, pratica vários esportes radicais.

Em uma de suas viagens de férias, Roberto sofre grave acidente e não resiste. Os médicos socorristas entram em contato com Iza, que providencia as medidas funerárias. Dias após o ocorrido, Iza recebe um telefonema do advogado de Roberto, que deseja informá-la sobre o testamento do irmão.

Ao tomar ciência do conteúdo do documento, Iza não poderia ficar mais surpresa: o testamento de Roberto deixa todo o patrimônio para uma instituição neonazista e antissemita que se destaca internacionalmente por propagar o ódio.

Inconformada, Iza deseja invalidar essa escolha, que considera repugnante. Perguntase, então: o Direito permite que se julgue o mérito dessa disposição para declarar nulo o testamento de Roberto?

Pretende-se responder positivamente a essa pergunta, bem como a outros questionamentos adjacentes, nas linhas que se seguem. E acredita-se que o tema está na ordem do dia.

Isso porque se pode perceber atualmente movimentos na jurisprudência, legislação e doutrina para flexibilizar dois vetores históricos da sucessão testamentária: o apego ao formalismo do ato e a atenção à capacidade do testador.

Sabe-se que o rigor formal do testamento, com solenidades a serem observadas na conclusão do negócio, sempre foi muito caro ao Direito das Sucessões brasileiro ${ }^{6}$. O Código Civil conta até hoje com seis tipos de testamentos, sendo três ordinários e três especiais ${ }^{7}$, cada

\footnotetext{
${ }^{6}$ Por todos, confira-se: GOMES, Orlando. Sucessões. 16 a ed. rev. e atual. por Mario Roberto Carvalho de Faria. Rio de Janeiro: Forense, 2015, pp. 147-148.

${ }^{7} \mathrm{O}$ estudo detalhado das espécies e tipos de testamento não é objeto deste trabalho, motivo pelo qual apenas se pontua brevemente o tema. A sistemática da sucessão testamentária estabelece duas espécies de testamento: os testamentos ordinários e os testamentos especiais. Em cada uma dessas espécies estão previstos tipos de testamento, de forma taxativa (art. 1.887 do Código Civil). São três tipos de testamento ordinário: $(a)$ público; $(b)$ cerrado; e $(c)$ particular. E são também três tipos de testamento especiais: $(a)$ marítimo; $(b)$ aeronáutico; e $(c)$ militar. O testamento público é elaborado perante o tabelião ou autoridade competente investida pelo Estado nesta
} 
um com formalidades próprias. E a tradição dos tribunais historicamente faz reverência ao formalismo, a ponto de se anularem testamentos que escapam a detalhes de menor impacto substancial $^{8}$.

No entanto, nos últimos anos, os tribunais passaram a dispensar algumas formalidades e o STJ tem apontado na direção de prestigiar a validade dos testamentos mesmo na ausência de alguma das formalidades previstas em lei.

Num desses $\operatorname{casos}^{9}$, o STJ flexibilizou o conceito de unidade do testamento $^{10}$. Tratavase do testamento do banqueiro Amador Aguiar: o testador, que já contava com mais de 80 anos e com saúde física frágil, enviou minuta de testamento ao tabelião, que lavrou a escritura no cartório e, no dia seguinte, a levou para leitura e assinatura na casa de Amador Aguiar. O testador e as testemunhas presenciaram a leitura e assinatura do testamento, mas não

função (representantes consulares, por exemplo). Como requisitos de validade (quanto à forma), o testamento público deve ser lavrado em cartório (representação consular ou equivalente), lido ao testador e a duas testemunhas e assinado por todos. O testamento cerrado é de conhecimento exclusivo do testador, só ele sabe o seu conteúdo. Neste caso, também há a figura do tabelião (ou autoridade competente investida pelo Estado nesta função), que elabora o auto de aprovação. Sem o auto de aprovação, o testamento cerrado sequer existe (enquanto testamento cerrado), de forma que o auto de aprovação é elemento categorial inderrogável do testamento cerrado. Nos ensinamentos de Paulo Lôbo, "[e]nquanto não houver auto de aprovação não haverá ato jurídico perfeito" (LÔBO, Paulo. Sucessões. São Paulo: Saraiva, 2013, p. 224). Como requisito de validade, o testamento cerrado deve ser lacrado ao ser entregue ao notário, na presença de duas testemunhas, que devem assinar o auto de aprovação junto com o testador. Já o testamento particular é celebrado pelo testador sem a presença de tabelião (ou equivalente) e pode ser escrito de próprio punho ou através de processo mecânico (contanto que não deixe espaços em branco ou rasuras, de acordo com o art. 1.876 do Código Civil). Como requisito de validade de forma, o testamento particular deve ser lido em voz alta na presença (e com a assinatura) de três testemunhas. Pode ser feito de emergência, em circunstâncias excepcionais, sem testemunhas, desde que escrito de próprio punho (art. 1.879 do Código Civil). Sobre os testamentos especiais, tanto o testamento marítimo quanto o testamento aeronáutico são tratados da mesma maneira. São formas testamentárias cuja base é a impossibilidade de testar pelas vias ordinárias. É elemento categorial inderrogável desse tipo de testamento que o navio (ou avião) não esteja em (aero)porto. Para que seja válido o testamento marítimo o ato deve ser praticado na presença do comandante e de mais duas testemunhas; e o aeronáutico deve ser praticado na presença de pessoa designada pelo comandante. A eficácia, tanto do testamento marítimo quanto do aeronáutico, depende da morte do testador em até 90 dias contados do desembarque em local onde se possa testar pelas formas ordinárias, sob pena de caducidade (art. 1.891 do Código Civil). O testamento militar, por sua vez, é pensado para os casos em que o testador está a serviço das Forças Armadas e tem como requisito de validade a presença de duas ou três testemunhas (art. 1.893 do Código Civil). Na linha dos testamentos marítimo e aeronáutico, também caduca o testamento militar quando o testador não falece em até 90 dias contados da possibilidade de testar pelas formas ordinárias (art. 1.895 do Código Civil).

${ }^{8}$ Confira-se, por exemplo, os julgados: STF, $2^{\mathrm{a}} \mathrm{T}, \mathrm{RE} \mathrm{n}^{\circ}$ 62.132/MG, Rel. Min. Adalício Nogueira, v. u., j. 1.10.1968; STJ, REsp n ${ }^{\circ}$ 151.398/SP, $4^{\text {a }}$ T, Rel. Min. Sálvio de Figueiredo Teixeira, Rel. p/ acórdão Min. Ruy Rosado De Aguiar, v. m., j. 16.5.2000; STJ, $3^{\text {a }}$ T, REsp no 294.691/PR, Rel. Min. Carlos Alberto Menezes Direito, v. u., j. 13.3.2001.

${ }^{9}$ Trata-se do Recurso Especial n ${ }^{\text {o } 753.261 / S P, ~} 3^{\mathrm{a}}$ T, Rel. Min. Paulo de Tarso Sanseverino, v. u., j. 23.11.2010.

${ }^{10}$ A "unidade do ato no testamento", nas palavras de Orlando Gomes, "interpreta-se no sentido de contexto único, que implica presença simultânea dos participantes e prática dos atos sem solução de continuidade. Não se parte a cédula, nem se permite revezamento das testemunhas" (GOMES, Orlando. Sucessões. 16a ed. rev. e atual. por Mario Roberto Carvalho de Faria. Rio de Janeiro: Forense, 2015, p. 116). 
presenciaram o momento em que o tabelião redigiu o instrumento ${ }^{11}$. O STJ manteve a validade do ato que, no entendimento do Tribunal, não violou o princípio da unidade do testamento.

Recentemente, o TJRJ declarou válido o testamento particular de Ivan Paez Soares, sem assinatura de testemunhas ${ }^{12}$. O acórdão observou que "o STJ vem mitigando a exigência da observância estrita dos requisitos legais do testamento, sob o fundamento de que a formalidade não pode se sobrepor ao seu conteúdo"13, motivo pelo qual se entendeu que, mesmo faltando um requisito formal, o testamento deveria ser cumprido.

Além disso, está pendente de julgamento na $2^{\mathrm{a}}$ seção do STJ um caso que se discute a formalidade de testamento particular sem a assinatura por escrito da testadora, Nilza Aguiar Boavendorp, mas com sua impressão digital. A Corte iniciou o julgamento em 11.12.2019, com voto da Min. Nancy Andrighi pela validade do testamento, momento em que o Min. Ricardo Villas Bôas Cueva pediu vista dos autos ${ }^{14}$.

Também não se está muito distante de discutir a validade de testamento formado por meio eletrônico ${ }^{15}$. A Corte de Apelações do Michigan recentemente declarou a validade do

\footnotetext{
${ }^{11} \mathrm{O}$ acórdão traz notícia de que o argumento dos herdeiros foi acompanhado de parecer de Rui Geraldo Camargo Viana, que afirma haver, "inequivocamente, quebra da unidade do ato, quando o testamento é redigido no Cartório de Notas, sem a presença do testador e das testemunhas, baseado em minuta previamente elaborada, e, somente depois de dias, ser levado à casa do testador para ser assinado por ele e pelas testemunhas". Contrariamente, ou seja, pela possibilidade de desmembramento do ato, foi apresentado parecer de Ruy Rosado de Aguiar Jr., para quem "não teria validade o testamento se a declaração de vontade do testador ocorresse em certo dia e local, e as assinaturas das testemunhas fossem colhidas em outro. Na espécie, essa unicidade foi guardada, pois, no dia consignado no instrumento, aconteceu a declaração do testador, a leitura do texto e a sua assinatura, com a

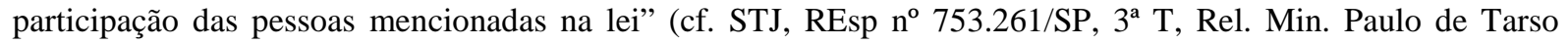
Sanseverino, v. u., j. 23.11.2010).

${ }^{12}$ Conforme exige o art. 1.876 do Código Civil, o testamento particular deve ser assinado por três testemunhas que devem posteriormente confirmar o instrumento perante o juiz no procedimento de abertura, cumprimento ou publicação de testamento (na forma do art. 1.878 do Código Civil).

${ }^{13}$ TJRJ, $11^{\mathrm{a}} \mathrm{CC}, \mathrm{AC} \mathrm{n}^{\circ}$ 0042062-25.2015.8.19.0002, Rel. Des. Fernando Cerqueira Chagas, j. 8.5.2019. No caso, o Tribunal também considerou a "circunstância trágica e excepcionalíssima, do seu suicídio [de Ivan Paez Soares], cinco dias depois de manifestar a sua vontade testamentária. Mesmo que premeditado, não pode ser exigido do seu autor a frieza de que tomasse todas as providências necessárias, com a observância estrita de todos os requisitos legais, para que fossem cumpridas suas últimas vontades", independentemente do fato de ser o testador "advogado militante, provável conhecedor da matéria".

${ }^{14}$ Trata-se do REsp no 1.633.254/MG, distribuído à segunda Seção do STJ sob relatoria da Min. Nancy Andrighi. A testadora Nilza Aguiar Boavendorp teve quatro filhos e o testamento contemplou apenas uma filha da testadora. Pode-se ler a notícia do voto da Min. Nancy Andrighi em: STJ: Nancy valida testamento que contou apenas com impressão digital da testadora. Migalhas, publicado em 11.12.2019, disponível em: 〈hitps//www.migalhas.combr/Quentes/17,MI316917,81042-STJ+Nancy+validattestamento+quetcontou+apenas+com+impressao+digital〉.

Acessado em 11.12.2019.

${ }^{15}$ Atualmente, o testamento eletrônico "poderia significar qualquer texto dentro de um amplo espectro que vai de um testamento simplesmente digitado em um programa de processamento de texto pelo testador em um computador e armazenado em seu disco rígido até um testamento assinado pelo testador por meio de uma assinatura digital, testemunhada e autenticada via webcam, e armazenada por uma empresa com fins lucrativos" (tradução livre). No original: "as used today, an electronic will could mean any writing along a broad spectrum
} 
testamento de Duane Francis Horton II - basicamente um arquivo de texto digitado que Horton armazenou no aplicativo Evernote em seu celular ${ }^{16}$. Pouco antes de morrer, Horton escreveu um bilhete alertando que sua "carta final" estaria no telefone. A nota do aplicativo, de fato, destacava desculpas e sentimentos do testador, instruções funerárias e disposições patrimoniais que excluíram Lanora Jones, sua mãe, da sucessão.

O Tribunal se convenceu de que a nota no aplicativo Evernote traduzia a última vontade de Horton, de modo a estar comprovada a sua intenção de fazer daquele documento o seu testamento - o que, de acordo com as leis do Michigan, é suficiente para instruir a sucessão testamentária.

Na Austrália, a Supreme Court of Queensland também considerou como testamento válido uma série de documentos armazenados no iPhone do testador, Karter $\mathrm{Yu}$ - um deles que se iniciava com os dizeres "esse é minha última vontade e testamento" ${ }_{17}$. No caso, as leis de sucessão australianas também permitiram ao Tribunal reconhecer como testamento válido um documento que demonstrasse a intenção de testar.

from a will simply typed into a word-processing program by the testator on a computer and stored on its hard drive to a will signed by the testator with an authenticated digital signature, witnessed or notarized via webcam, and stored by a for-profit company". O tema é bastante interessante e comporta análise por alguns cenários diferentes: a "Pessoa A cria um documento no Word de seu computador, intitula de 'MeuTestamento.doc', e digita como ela quer que distribuam seus bens. Ao final do documento, ela digita 'Assinado, Pessoa A'. Pessoa B acessa sua conta no Facebook e usa o serviço de mensagem da plataforma para enviar uma mensagem para um amigo: 'Oi. Estou no hospital. Só em caso de alguma coisa acontecer comigo eu quero que todos os meus bens fiquem com a minha mãe. Não apague essa mensagem'. Pessoa C cria uma conta em um site de uma empresa startup que ajuda pessoas a criarem testamentos eletrônicos. Ela preenche um formulário básico a partir do qual a empresa gera o documento 'Última Vontade e Testamento'. A startup realiza uma cerimônia online de execução do testamento, permitindo que duas outras pessoas 'testemunhem' o testamento e um notário autentique o testamento via webcam. A startup promete manter o testamento armazenado de modo seguro no servidor e em formato acessível pelos próximos trinta anos por uma taxa fixa que a Pessoa C paga antecipadamente". No original: "Person A creates a Word document on her computer, titles it "MyWill.doc," and types out how she wants her property to be disposed of. At the end of the document, she types: "Signed, Person A." Person B logs into her Facebook account and uses the messaging interface to send a message to a friend: "H ey I'm in the hospital. J ust in case something happens to me I want all my property and items to go to my mom. Don't delete this message." Person C creates an account on the website of a startup that helps people create electronic wills. She fills out a basic form, from which the startup generates a "Last Will and Testament" document. The startup then performs an online will execution ceremony, allowing two other people to "witness" the will and a notary to notarize the will via webcam. The startup promises to keep the will safely stored on its server in an accessible, electronic format for the next thirty years for a flat fee that Person C pays upfront" (DEVELOPMENTS in the Law - More Data, More Problems. 131 Harvard Law Review 1715, 1790. Publicado em 10.4.2018. Disponível em: <https://harvardlawreview.org/2018/04/what-is-an-electronic-will/>. Acessado em 19.11.2019).

${ }^{16}$ TRUSTS and estates - Electronic wills - Michigan Court of Appeals holds electronic document to be valid will under harmless error rule - In re Estate of Horton, No. 339737 (Mich. Ct. App. July 17, 2018) (per curiam). 132 Harvard Law Review 2082. Publicado em 10.5.2019. Disponível em: <https://harvardlawreview.org/2019/05/inre-estate-of-horton/>. Acessado em 19.11.2019.

17 Austrália, Supreme Court of Queensland, Re: Yu [2013] QSC 322, j. 6.11.2013. Disponível em: <https://perma.cc/RK45-GL3B>. Acessado em 19.11.2019. 
Entre nós, o Instituto Brasileiro de Direito de Família (IBDFAM) lidera iniciativa de “Anteprojeto de lei para reforma do Direito das Sucessões" que autoriza todas as formas de testamento ordinário por instrumentos digitais ${ }^{18}$.

Ao mesmo tempo em que se suavizam as exigências sobre a forma, notam-se também inovações legislativas que flexibilizaram a capacidade civil, notadamente o Estatuto da Pessoa com Deficiência (Lei n ${ }^{\circ} 13.106$ de 2015) - havendo quem sustente, por exemplo, a capacidade testamentária ativa das pessoas submetidas aos novos regimes de curatela e de tomada de decisão apoiada ${ }^{19}$.

\footnotetext{
${ }^{18}$ A proposta do IBDFAM, sob a coordenação de Mário Luiz Delgado na parte de sucessão testamentária, se inicia com a inclusão de parágrafo único ao art. 1.862 do Código Civil: "Os testamentos ordinários podem ser escritos ou realizados por sistema digital de som e imagem, desde que gravadas imagens e voz do testador e das testemunhas". Para o testamento particular, confira-se a inclusão de inciso no art. 1.864: "São requisitos essenciais do testamento público: [...] IV - se realizada a gravação do ato em sistema digital de som e imagem, esta será exibida pelo tabelião ao testador e a duas testemunhas, a um só tempo; que confirmarão, por escrito, o teor das declarações". Quanto ao testamento cerrado, veja-se a proposta para o art. 1.868 do Código Civil: "O testamento escrito ou gravado em sistema digital de som e imagem pelo testador, ou por outra pessoa, a seu rogo, será válido se aprovado pelo tabelião ou seu substituto legal, observadas as seguintes formalidades: I - que o testador entregue a cédula ou o arquivo digital ao tabelião em presença de duas testemunhas. [...] Parágrafo único. Quando escrito mecanicamente o testamento cerrado, o subscritor deve numerar e autenticar, com a sua assinatura, todas as páginas. Quando filmado, deve o testador verbalizar, com a própria voz, antes de encerrar a gravação, ser aquele o seu testamento". E também o art. 1.869 do Código Civil: "O tabelião deve começar o auto de aprovação declarando, sob sua fé, que o testador lhe entregou a declaração escrita ou o arquivo digital para ser aprovado na presença das testemunhas; passando a cerrar e coser o instrumento ou o involucro em que inserido o arquivo digital". Para o testamento particular, confira-se o teor do art. 1.876 do Código Civil: "O testamento particular pode ser escrito de próprio punho ou mediante processo mecânico ou gravação em sistema digital de som e imagem ou outro programa audiovisual. [...] $\$ 3^{\circ}$ Se realizado por sistema digital de som e imagem deve haver nitidez, clareza na transmissão de imagens e sons, sendo esses os requisitos essenciais à sua validade, além da presença de duas testemunhas identificadas nas imagens. $\S 4^{\circ} \mathrm{O}$ testamento deverá ser gravado em formato compatível com os programas computadorizados de leitura existentes na data da celebração do ato, contendo a declaração do testador de que no vídeo consta o seu testamento, bem como a sua qualificação completa e das testemunhas". Também o art. 1.881 do Código Civil: "Toda pessoa capaz de testar poderá, mediante escrito particular seu, datado e assinado, ou ainda mediante gravação em programa audiovisual, fazer disposições especiais sobre o seu enterro, sobre esmolas de pouca monta a certas e determinadas pessoas, ou, indeterminadamente, aos pobres de certo lugar, assim como legar móveis, roupas ou joias, de pouco valor, de seu uso pessoal". Para compatibilização entre os sistemas civil e processual, o anteprojeto também pretende alterar o Código de Processo Civil neste aspecto, conferindo nova redação ao art. 737 do Código de Processo Civil: " $\$ 3^{\circ}$ Aplica-se o disposto neste artigo ao codicilo e ao testamento feito por sistema audiovisual". Em justificativa, o IBDFAM aponta a facilidade de mecanismos audiovisuais: "abre-se uma nova possibilidade de uso de recursos tecnológicos, precisamente o audiovisual. Na quadra em que vivemos, no que se convencionou chamar de sociedade da informação, onde tais recursos são amplamente admitidos como meio de prova em quaisquer instâncias, não seria mais aceitável desconhecê-los como instrumentos válidos de elaboração do testamento. [...] Adotadas as cautelas previstas no anteprojeto, nenhum registro poderia ser mais fiel à última vontade do autor da herança do que aquele feito em sistema de audiovisual" (Disponível em: 〈http://ibdfam.org.br/assets/upload/anteprojeto_sucessoes/anteprojeto_sucessoes.pdf $>$. Acessado em 3.5.2018).

${ }^{19}$ Sobre o tema: MENEZES, Joyceane Bezerra de; LOPES, Ana Beatriz Pimentel. A sucessão testamentária da pessoa com deficiência intelectual e/ou psíquica. In: TEIXEIRA, Daniele Chaves (coord.). Arquitetura do planejamento sucessório. Belo Horizonte: Fórum, 2019, pp. 159-174.
} 
Se o apego ao formalismo e o rigor com a capacidade do testador têm sido mitigados, é de se especular se essas tendências de flexibilização podem avançar sobre outro vetor histórico da sucessão testamentária no Brasil: o respeito às escolhas do testador.

Isso porque são raros os casos que enfrentaram diretamente uma análise do conteúdo do testamento, mas, em contrapartida, não são tão raros os casos que verificam a presença de vício do consentimento no ato. Além disso, não é incomum no repertório dos nossos tribunais se verificarem casos que anulam o testamento - base na captação dolosa da vontade do testador perante situações que parecem omitir a relevância de julgamentos morais sobre o conteúdo das disposições ${ }^{20}$.

A provocação, então, é inevitável. Uma vez que se aceite flexibilizar as formalidades do testamento e a capacidade de testar, o próximo passo tende a ser avançar sobre o mérito das disposições testamentárias. Acredita-se que se está em tempo de se permitir a discussão sobre o conteúdo dos testamentos, sem rodeios.

Essa questão já chegou aos tribunais brasileiros, conforme rumoroso caso de que se tem notícia, julgado em Guaxupé, no Estado de Minas Gerais. Trata-se da sucessão de Lenira Faria Silva Barbosa, casada com Orostrato Olavo, com quem teve Olavo, Silvia e Maria Cristina. Por sua vez, tanto Silvia quanto Maria Cristina se casaram e tiveram filhos, netos de Lenira ${ }^{21}$. Já Olavo teve duas filhas frutos de relacionamentos "não maritais"22 (Ana Caroline e Mariana).

Em 2004, Lenira elaborou testamento que distribuiu toda a sua parte disponível em três legados: 1/3 para os netos filhos de Silvia, 1/3 para os netos filhos de Maria Cristina e 1/3 para os netos filhos de Silvia e Maria Cristina, em conjunto. A testadora não contemplou, portanto, as netas Ana Caroline e Mariana, filhas de Olavo.

Nesse contexto, Ana Caroline e Mariana ajuizaram ação ordinária para requerer sua inclusão no testamento de Lenira alegando que foram excluídas por discriminação quanto à origem da filiação. A sentença parcial reconheceu o direito de Ana Caroline e Mariana sob 1/3 da parte disponível dos bens da testadora.

\footnotetext{
${ }^{20}$ Não passa despercebido que, por vezes, alguns casos parecem enfrentar o conteúdo por via transversa. A este respeito remetemos ao nosso trabalho anterior: TOLEDO, Maria Beatriz de Miranda. Captação dolosa da vontade do testador. Trabalho de conclusão de curso (Bacharelado em Direito). Ibmec, Rio de Janeiro, 2014.

${ }^{21}$ Silvia teve três filhos (Flávia, César e Fabiana) e Maria Cristina teve dois filhos (Sérgio e Thaís).

${ }^{22}$ Nas palavras da sentença parcial (TJMG, $1^{\text {a }}$ Vara Cível de Guaxupé, Processo no 0058435-49.2017.8.13.0287, juiz Milton Biagioni Furquim, j. 16.7.18).
} 
Percebe-se, por esse e outros casos, que a sucessão testamentária - e, mais amplamente, o planejamento sucessório ${ }^{23}$ - está na ordem do dia, e o debate sobre as limitações ao seu conteúdo precisa ser enfrentado.

É por isso que este trabalho se propõe a dissertar sobre um problema: até que ponto um julgador está autorizado a fazer juízo de valor sobre o mérito das escolhas do testador?

Esse problema pode ser discutido sobre o ponto de vista de um dever ser - ou seja, podese perguntar se é desejável ou não, apropriado ou inconveniente, que se permita esse tipo de investigação. Não é essa, todavia, a perspectiva adotada neste trabalho.

Parte-se aqui da premissa de que o exame do mérito das escolhas do testador é desejável, de modo que o propósito desse estudo é o de investigar o ser - isto é, saber em quais situações essa análise é juridicamente adequada. Escolhe-se, portanto, a dogmática do Direito Civil como caminho metodológico para traçar os contornos dos espaços de discussão da validade do conteúdo das disposições testamentárias.

Para isso, opta-se por partir de uma das contribuições teóricas mais relevantes do Direito Civil brasileiro: a teoria do negócio jurídico da maneira como Antonio Junqueira de Azevedo a descreve ${ }^{24}$. A formulação de Antonio Junqueira de Azevedo destaca a estrutura do negócio jurídico e os seus três planos - de existência, validade e eficácia.

Diante dela, pode-se verificar que a revisão de mérito das escolhas testamentárias está inserida no âmbito da filtragem do conteúdo das disposições. Está-se, assim, diante do plano da validade - em especial, diante do fenômeno da nulidade das disposições testamentárias, uma vez que o Código Civil brasileiro diferencia as invalidades entre nulidades e

\footnotetext{
${ }^{23}$ São exemplos de instrumentos de planejamento sucessório as doações, a constituição de sociedades empresárias, de planos de previdência privada e de trusts fora do Brasil. Entretanto, todas essas ferramentas apresentam alguma carga de risco, seja tributário ou de cumprimento da vontade do autor da sucessão. O testamento, diante dessas demais ferramentas de planejamento sucessório, é aquele que reúne as melhores condições para cumprir a vontade do autor da herança, com algumas vantagens: ( $a$ ) oferece segurança jurídica por estar detalhadamente regulado no Código Civil; $(b)$ tem três tipos ordinários e o testador pode escolher o que lhe for mais conveniente; $(c)$ permite ao testador organizar completamente seu patrimônio, distribuir seus bens entre os herdeiros necessários e instituir legatários; $(d)$ permite ao testador tratar de questões extrapatrimoniais (reconhecer filiação, por exemplo) e de diretrizes gerais (determinar rituais para seu corpo e alma, conselhos e orientações de negócios); e (e) pode complementar outros instrumentos de planejamento sucessório ou funcionar como instrumento centralizador da sucessão.

${ }^{24}$ Parte-se das premissas definidas por Antonio Junqueira de Azevedo em suas principais obras sobre o negócio jurídico: AZEVEDO, Antonio Junqueira de. Negócio jurídico: existência, validade e eficácia. $4^{a}$ ed. São Paulo: Saraiva, 2002; e AZEVEDO, Antonio Junqueira de. Negócio jurídico e declaração negocial: noções gerais e formação de declaração negocial. Tese (Professor Titular). Faculdade de Direito, Universidade de São Paulo, São Paulo, 1986.
} 
anulabilidades, relegando os problemas de formação da vontade a hipóteses de anulabilidade, ao passo que a filtragem de conteúdo se dá mediante nulidades. Por isso, este trabalho se concentra nas nulidades e não nas anulabilidades. Além disso, este trabalho assume necessariamente que analisa testamentos sem vícios de declaração de vontade do testador ou vícios de forma, pois seu foco é o conteúdo das declarações.

Adianta-se, então, qual é o espaço dogmático para enfrentar o problema que se propõe: o filtro de validade do conteúdo das disposições testamentárias, à luz da teoria do negócio jurídico.

A tarefa parece desafiadora. Afinal, o fenômeno sucessório não é simples. Como diz o próprio Antonio Junqueira de Azevedo, nosso Direito das Sucessões é "bem mais complexo do que parece usualmente nas lições acadêmicas"25. E o estudo do Direito das Sucessões, como afirma Giselda Maria Fernandes Novaes Hironaka, pressupõe uma reflexão sobre o delicado tema da morte, o "pressuposto fundamental inafastável" ${ }^{26}$ da sucessão mortis causa ${ }^{27}$. É de onde se parte, portanto.

\footnotetext{
${ }^{25}$ AZEVEDO, Antonio Junqueira de. "O espírito de compromisso do direito das sucessões perante as exigências individuais de autonomia da vontade e as supra-individualidades da família. Herdeiro e legatário". Revista Da Faculdade De Direito, Universidade De São Paulo, 95, p. 281. Disponível em: <http://www.revistas.usp.br/rfdusp/article/view/67469>, acessado em 20.4.2018. Sobre os sistemas sucessórios, confira-se: CAPELO DE SOUSA, Rabindranath. Lições de direito das sucessões. Vol. I. $4^{\mathrm{a}}$ ed. Coimbra: Coimbra Editora, 2000, pp. 87-131. Em síntese, o autor aponta três sistemas sucessórios: $(a)$ individual-capitalista, $(b)$ familiar e $(c)$ socialista. No sistema individual-capitalista há uma prevalência ilimitada da sucessão testamentária sobre a sucessão legítima; no sistema familiar a sucessão legal é a regra, em benefício dos parentes do autor da sucessão, e a sucessão testamentária, "se houver, tem um caráter restrito e excepcional"; e no sistema socialista, poucos são os bens transmissíveis aos sucessores do autor da herança, a maior parte dos bens é obrigatoriamente destinada ao Estado, com limitações inclusive à capacidade de testar, que "não pode prejudicar o interesse público".

${ }^{26}$ HIRONAKA, Giselda Maria Fernandes Novaes. Morrer e suceder: passado e presente da transmissão sucessória concorrente. $2^{a}$ ed. São Paulo: Revista dos Tribunais, 2014, p. 20.

${ }^{27}$ Em síntese apurada, Maria de Nazareth Lobato Guimarães indica que o direito das sucessões é "a resposta aos problemas criados pela crise-morte nas relações patrimoniais, num contexto de apropriação individual dos bens", em que há "o desaparecimento do sujeito, aliado à permanência dos bens, de um lado, e, de outro, a necessidade de não deixar os bens abandonados, procurando, contudo, evitar a sua entrega sistemática ao Estado" (GUIMARÃES, Maria de Nazareth Lobato. Testamento e autonomia. Revista de direito e de estudos sociais. Coimbra: Centro de Direito Comparado da Faculdade de Direito, ano XVIII, ${ }^{\text {os }} 1$ 1-4, 1972, p. 22).
} 


\section{CONCluSÃo}

"The law of death is immortal"673.

Esta dissertação procura fotografar o espaço de revisão do conteúdo do testamento e discutir a adequação jurídica da análise de mérito das escolhas do testador à luz do panorama contemporâneo da sucessão testamentária - em que se percebe uma flexibilização dos requisitos legais sobre o formalismo do testamento e uma revisão da capacidade ativa do testador, dois vetores históricos da sucessão testamentária, por parte de legislação, doutrina e jurisprudência.

Para isso, aponta-se a dogmática do Direito Civil como caminho metodológico e partese da teoria do negócio jurídico, da maneira como Antonio Junqueira de Azevedo a descreve, como guia nessa trajetória.

Diante disso, pode-se verificar que a revisão de mérito das escolhas do testador está inserida estruturalmente no âmbito da filtragem de conteúdo do testamento, mais especificamente no plano da validade do negócio jurídico, determinando-se como sanção a nulidade das disposições testamentárias que contrariem determinadas pautas definidas por lei.

Destaque-se que a análise da validade das disposições testamentárias se insere no contexto imposto pelo espírito de compromisso do Direito das Sucessões brasileiro: o constante equilíbrio (o "pêndulo") entre a liberdade de testar e a proteção do patrimônio familiar. Essa tensão se reafirma quase que em todos os pontos deste trabalho.

Em síntese, este trabalho permite concluir que:

(a) a disciplina das invalidades é intrincada, o que repercute no estudo das nulidades das disposições testamentárias. Dessa forma, exige-se maior atenção por parte da ciência jurídica - e maior esforço interpretativo do julgador - na análise das hipóteses de nulidade das escolhas do testador;

(b) a análise de validade do conteúdo do testamento tangencia, em alguns casos, as concepções morais do julgador. No entanto, o controle valorativo das escolhas

\footnotetext{
${ }^{673}$ HIRSCH, Adam Jay. American History of Inheritance Law. Oxford International Encyclopedia of Legal History. Stanley N. Katz ed. 2009. FSU College of Law. Public Law Research Paper No. 258, p. 235. Disponível em: https://ssrn.com/abstract=982428>. Acessado em 19.11.2019.
} 
do testador (isto é, o exame da validade das suas disposições) deve se restringir às hipóteses escolhidas pelo legislador, afastando do intérprete o perigoso potencial de crítica moral das preferências do testador;

(c) as hipóteses de nulidade do negócio jurídico estabelecidas na Parte Geral do Código Civil se aplicam ao testamento, de forma que repercutem no conteúdo testamentário as nulidades previstas nos arts. 123, 137 e 166 do Código Civil;

(d) tais hipóteses gerais de nulidade têm contornos voláteis e devem ser lidas aos olhos das características de tempo e lugar adequados; assim, uma condição pode ou não ser considerada ilícita, ou contrária aos bons costumes, a depender de ter sido redigida ou analisada em 1920 ou 2020; no Brasil ou na China;

(e) notam-se crescente discussão sobre a validade de disposições testamentárias discriminatórias ou ofensivas à ordem pública, embora a questão não esteja disciplinada no ordenamento brasileiro como hipótese de nulidade. Nesse contexto, mais uma vez se percebe a tensão entre a liberdade de testar e a proteção de valores caros ao ordenamento. Entende-se que se está no momento de ampliar o debate de tais hipóteses, com os olhos postos em prestigiar os valores escolhidos pelo ordenamento jurídico brasileiro;

(f) o Código Civil impõe a filtragem do conteúdo nas hipóteses desenhadas nos arts. $1.900,1.848,1.959$ e 1.964 do Código Civil, também a reforçar o espírito de compromisso do nosso Direito das Sucessões entre a liberdade de testar e a proteção do patrimônio familiar;

(g) o testamenteiro é figura essencial à defesa da validade das disposições testamentárias, não podendo se esquivar da função ou atentar contra ela, salvo nos casos em que a nulidade é indefensável;

(h) o prazo de caducidade para se postular a nulidade das disposições é controvertido, havendo quem entenda pelo prazo de cinco anos (do art. 1.859 do Código Civil) e de quatro anos (do art. 1.909, parágrafo único, do Código 
Civil), o que pode vir a ser definido mediante a adoção do Anteprojeto de Lei apresentado pelo IBDFAM;

(i) há quem sustente a validade da cláusula de não impugnar a disposição testamentária que comina o herdeiro ou legatário da parte disponível com a perda da deixa; e

(j) há, também, quem defenda o cabimento da arbitragem em matéria sucessória, podendo ser, inclusive, imposta pelo testador aos herdeiros e legatários, na forma de cláusula compromissória testamentária.

O tema sobrevive, é claro, a este trabalho - quer se pensar que um tanto mais aceso do que antes -, merecendo debates que confiram maior segurança à prática do Direito das Sucessões e, sobretudo, maior conforto ao testador de que o mérito das suas disposições testamentárias há de passar exclusivamente por filtro de validade submetido a controle com base na lei e apoio dogmático, cujos contornos este trabalho pretende oferecer a conhecimento. 


\section{BIBLIOGRAFIA}

ALMEIDA, José Luiz Gavião de. In: AZEVEDO, Álvaro Villaça (coord.). Código Civil comentado. Vol. XVIII, 2003.

ALVIM, J. E. Carreira. Direito arbitral. Rio de Janeiro: Forense, 2007.

AMARAL, Francisco. Direito civil: introdução. $8^{\text {a }}$ ed. Rio de Janeiro: Renovar, 2014.

AMARAL NETO, Francisco dos Santos. Da irretroatividade da condição suspensiva no direito civil brasileiro. Rio de Janeiro: Forense, 1984.

AMAYUELAS, Esther Arroyo I; GARCIA, David Bondia. ¿Interpretación de testamento contraria a los derechos humanos? El caso Pla y Puncernau vs. Andorra (STEDH, 13 de julio de 2004)". P. 11. Disponível em: 〈https://dialnet.unirioja.es/descarga/articulo/1425341.pdf >. Acessado em 17.11.2019.

ANDRADE, Gustavo Henrique Baptista. $O$ direito de herança e a liberdade de testar: um estudo comparado entre os sistemas jurídicos brasileiro e inglês. Belo Horizonte: Fórum, 2019.

ANDREWS, Evan. Did a Premature Obituary Inspire the Nobel Prize? History Stories. Publicado em 9.12.2016. Disponível em: <https://www.history.com/news/did-a-prematureobituary-inspire-the-nobel-prize>. Acessado em 12.12.2019.

ANTONINI, Mauro. In: PELUSO, Cezar (coord). Código Civil comentado. $8^{\mathrm{a}}$ ed. Barueri: Manole, 2014.

ASCENSÃO, José de Oliveira. A teoria do negócio jurídico e o negócio testamentário em Portugal. Revista Brasileira de Direito das Famílias e Sucessões. Belo Horizonte: IBDFAM, n 18 , out.-nov./2010.

Direito civil: Sucessões. Coimbra: Coimbra Editora, 1981.

AZEVEDO, Álvaro Villaça. In: AZEVEDO, Álvaro Villaça (coord.). Código Civil Comentado. Vol. II. São Paulo: Atlas, 2003.

Do concubinato ao casamento de fato. Belém: CEJUP, 1986.

AZEVEDO, Antônio Junqueira de. Negócio jurídico: existência, validade e eficácia. $4^{\mathrm{a}}$ ed. São Paulo: Saraiva, 2002.

. Negócio jurídico e declaração negocial: noções gerais e formação de declaração negocial. Tese (Professor Titular). Faculdade de Direito, Universidade de São Paulo, São Paulo, 1986.

- "O espírito de compromisso do direito das sucessões perante as exigências individuais de autonomia da vontade e as supra-individualidades da família. Herdeiro e legatário". Revista Da Faculdade De Direito, Universidade De São Paulo, 95, pp. 273-281. Disponível em: <http://www.revistas.usp.br/rfdusp/article/view/67469>, acessado em 20.4.2018. 
. Ação de nulidade de testamento - Falta de legitimatio ad causam de quem não é herdeiro nem legatário - Os atos nulos podem, ou não, ser atos nulos "de pleno direito" Cânones hermenêuticos e interpretação das exigências de formalidades essenciais no testamento público. Revista Forense. Rio de Janeiro: Forense, vol. 345, jan.-mar./1999.

"A conversão do negócio jurídico: seu interesse teórico e prático". Revista da Faculdade de Direito da Universidade de São Paulo. São Paulo: Universidade de São Paulo, 1974, p. 183. Disponível em: 〈http://www.revistas.usp.br/rfdusp/article/view/66720/69330〉. Acessado em 9.6.2018.

AZEVEDO, Armando Dias de. O fideicomisso no direito pátrio. São Paulo: Saraiva, 1973.

. Do fideicomisso. Monografia (Professor de Direito Civil). Faculdade de Direito da Universidade de Porto Alegre, Porto Alegre, 1938.

BANDEIRA, Gustavo. A inconstitucionalidade da cláusula de inalienabilidade e da declaração de sua justa causa, prevista no novo Código Civil para os testamentos lavrados na égide do Código de 1916. Revista da EMERJ. Rio de Janeiro: EMERJ, vol. 6, n. 24, 2003.

BANDEIRA, Paula Greco. Contrato incompleto. São Paulo: Atlas, 2015, pp. 156-157; BESSONE, Darcy. Do contrato. Rio de Janeiro: Forense, 1960.

BAPTISTA, Luiz Olavo. Arbitragem comercial e internacional. São Paulo: Magister, 2011.

BARROS, Ricardo Leonel de. In: BUENO, Cassio Scarpinella (coord.). Comentários ao Código de Processo Civil. Vol. 1. São Paulo: Saraiva, 2017.

BENETI, Ana Carolina; RODOVALHO, Thiago. "Algumas considerações sobre a utilização da arbitragem no direito de família e sucessório no Brasil". In: TEIXEIRA, Daniele Chaves (coord.). Arquitetura do planejamento sucessório. Belo Horizonte: Fórum, 2009.

BETTI, Emilio. Teoria geral do negócio jurídico. Vol. II. Coimbra: Coimbra Editora, 1969.

BEVILÁQUA, Clóvis. Direito das sucessões. Bahia: Livraria Magalhães, 1899.

Código Civil dos Estados Unidos do Brasil comentado. Vol. VI. São Paulo: Livraria Francisco Alves, 1919.

BIANCA, C. Massimo. Diritto civile. Vol. II. $3^{\text {a }}$ ed. Milão: Dott. A. Giuffrè Editore, 2001.

BITTENCOURT, Edgard de Moura. O concubinato no direito. Vol 1. $2^{\mathrm{a}}$ ed. Rio de Janeiro: Ed. Jurídica e Universitária, 1969.

BUERES, Alberto J. Objeto del negocio jurídico. $2^{\mathrm{a}}$ ed. Buenos Aires: Hammurabi, 1998.

BUTRUCE, Vitor Augusto José. O design da ruptura dos contratos empresariais de prazo determinado. Tese (Doutorado em Direito Comercial). Faculdade de Direito, Universidade de São Paulo, São Paulo, 2019.

BRANCO, Sérgio. "A natureza jurídica dos direitos autorais". Civilistica.com. Rio de Janeiro, a. 2, n. 2, abr.-jun./2013. Disponível em: <http://civilistica.com/a-natureza-juridica-dosdireitos-autorais/>. Acessado em 29.4.2018. 
CAHALI, Francisco José. "Ensaio sobre arbitragem testamentária no Brasil com paradigma no direito espanhol". Revista de Arbitragem e Mediação. São Paulo: Revista dos Tribunais, vol. 17, abr.-jun./2008.

In: NANNI, Giovanni Ettore (coord.). Comentários ao Código Civil: direito privado contemporâneo. São Paulo: Saraiva, 2018.

CAMPOS, Francisco. Testamento. Captação - Quando invalida a disposição testamentária Relações amorosas entre o testador e a legatária - Desvelo incomum desta para com aquele Necessidade da existência de dolo para caracterização do domínio da vontade. Tutela. Instituição por testamento - Filho menor reconhecido - Sobrevivência, todavia, da mãe deste ao testador - Pátrio poder devolvido a ela - Hipótese em que subsiste a disposição testamentária - Aplicação do art. 384, n. IV do Código Civil. Vínculo. Disposição testamentária prescrevendo a inalienabilidade de ações compreendidas na legítima do filho do testador - Restrição imposta no sentido de, em caso de sub-rogação, poderem elas ser vendidas somente a determinada pessoa - Validade da cláusula. Revista dos Tribunais. São Paulo: Revista dos Tribunais, vol. 197.

CAPELO DE SOUSA, Rabindranath. Lições de direito das sucessões. Vol. I. $4^{\mathrm{a}}$ ed. Coimbra: Coimbra Editora, 2000.

CARMONA, Carlos Alberto. Arbitragem e processo. $3^{\text {a }}$ ed. São Paulo: Atlas, 2009.

CARNEIRO, Athos Gusmão. Testamento - Condição juridicamente impossível. Revista Forense. Rio de Janeiro: Forense, vol. 91, nº 332, out.-dez./1995.

CARNELUTTI, Francesco. Captazione del testamento e indegnità a sucedere. Rivista di Diritto Civille. Milão: Società Editrice Libraria, 1933.

CARVALHO, Francisco Pereira de Bulhões. Sistema de nulidades dos atos jurídicos. Rio de Janeiro: Forense, 1980.

CASTRO, Thamis Dalsenter Viveiros de. Bons costumes no Direito Civil brasileiro. São Paulo: Almedina, 2017.

CHALMERS, James. Testamentary conditions and public policy. In: REID, Keneth; WAAL, Marius de; ZIMMERMANN; Reinhard (ed.). Exploring the law of succession. Edinburg: Edinburg University Press, 2007.

CHINELLATO, Silmara Juny de Abreu. "Obras póstumas e direito de autor". In: SIMÃO, José Fernando; BELTRÃO, Silvio Romero (coord.). Direito civil: estudos em homenagem a José de Oliveira Ascensão. Vol. 1. São Paulo: Atlas, 2015.

CONTINENTINO, Mucio. Da clausula penal no direito brasileiro. São Paulo: Saraiva, 1926.

COPSON, Andrew. Schools which gender discriminate should not be allowed to split in order to evade court ruling. The Telegraph. Publicado em 31.10.2017. Disponível em: $<$ https://www.telegraph.co.uk/education/2017/10/31/schools-gender-discriminate-should-notallowed-split-order-evade/>. Acessado em 16.11.2019. 
CORDEIRO, Antônio Menezes. Tratado da arbitragem: comentários à Lei 63/2011, de 14 de dezembro. Coimbra: Almedina, 2016.

CORTIANO JUNIOR, Eroulths. Sucessão e cláusulas restritivas. In: TEIXEIRA, Daniele Chaves (coord.). Arquitetura do planejamento sucessório. Belo Horizonte: Fórum, 2019.

CORTIANO JUNIOR, Eroulths; RAMOS, André Luiz Arnt. Liberdade testamentária versus sucessão forçada: anotações preliminares sobre o direto sucessório brasileiro. Revista de Estudos Jurídicos e Sociais. Cascavel: NEJUS, n 4, maio/2015. Disponível em: Disponível em: <https://www.univel.br/sites/default/files/revistajuridica/revista_04_edition.pdf>. Acessado em 3.10.2019.

CUBARRUBIA, RJ. “Adam Yauch's Will Prohibits Use of His Music in Ads”. Rolling Stones. Disponível em: <https://www.rollingstone.com/music/news/adam-yauchs-will-prohibits-useof-his-music-in-ads-20120809>. Acessado em 29.4.2018.

DECOLAR.COM é multada em R \$ 7,5 milhões por diferenciar preço de acordo com região. Migalhas, publicado em 19.6.2018, disponível em: <http://www.migalhas.com.br/Quentes/17,MI282013,61044Decolarcom+e+multada+em+R+75+milhoes+por+diferenciar+preco+de+acordo $>$. Acessado em 17.4.2019.

DELGADO, Mário Luiz. Problemas de Direito Intertemporal no Código Civil. São Paulo: Saraiva, 2004.

DEGNI, Francesco. Lezioni di diritto civile: la successione a causa di morte. Vol. II. $2^{\mathrm{a}}$ ed. Padova: CEDAM, 1936.

DICIONÁRIO Michaelis. Editora Melhoramentos, 2019, versão eletrônica, disponível em: $<$ http://michaelis.uol.com.br/busca? $\mathrm{r}=0 \& \mathrm{f}=0 \& \mathrm{t}=0 \&$ palavra=discriminar $>, \quad$ acessado $\mathrm{em}$ 17.4.2019.

DICKSTEIN, Marcelo. Nulidades prescrevem?: uma perspectiva funcional da invalidade. Rio de Janeiro: Lumen Juris, 2015.

DIDIER JR., Fredie; BRAGA, Paula Sarno. Carta psicografada como fonte de prova no processo civil. Revista do Programa de Pós-Graduação em Direito da Universidade Federal da Bahia. Vol. 23. $\mathrm{N}^{\mathrm{o}} 25.2013 .2$ Disponível em: <https://portalseer.ufba.br/index.php/rppgd/article/view/12366/9413>. Acessado em 19.12.2019.

DUARTE, Nestor. In: PELUSO, Cezar (coord). Código Civil comentado. $8^{\mathrm{a}}$ ed. Barueri: Manole, 2014.

CARVALHO, Luiz Paulo Vieira. Direito das sucessões. $2^{\text {a }}$ ed. São Paulo: Atlas, 2015.

DEVELOPMENTS in the Law - More Data, More Problems. 131 Harvard Law Review 1715, 1790. Publicado em 10.4.2018. Disponível em: <https://harvardlawreview.org/2018/04/whatis-an-electronic-will/>. Acessado em 19.11.2019 
DIAS, Maria Berenice. Manual das sucessões. $3^{\mathrm{a}}$ ed. São Paulo: Editora Revista dos Tribunais, 2013.

DINIZ, Maria Helena. In: AZEVEDO, Antônio Junqueira de (coord.). Comentários ao Código Civil, v. 22. São Paulo: Saraiva, 2003.

. Curso de direito civil brasileiro. Vol. 6. 26ª ed. São Paulo: Saraiva, 2012.

ESPÍNOLA, Eduardo. Questões jurídicas e pareceres. São Paulo: Editora Monteiro Lobato, 1925.

FARIA, Mario Roberto Carvalho de. Direito das sucessões. $8^{\mathrm{a}}$ ed. Rio de Janeiro: Forense, 2018.

FARIAS, Cristiano Chaves de; ROSENVALD, Nelson. Curso de direito civil: sucessões. Vol. 7. São Paulo: Atlas, 2015.

FELLET, João. Monarquistas ocupam cargos em Brasília e reabilitam grupo católico ultraconservador. $B B C$ News Brasil. Publicado em 4.4.2019. Disponível em: <https://www.bbc.com/portuguese/brasil-47728267>.Acessado em 16.12.2019.

FERNANDES, Luís A. Carvalho. Lições de direito das sucessões. $4^{\mathrm{a}}$ ed. Lisboa: Quid Juris?, 2012.

FERREIRA, Aurélio Buarque de Holanda. Novo Aurélio Século XXI: o dicionário da língua portuguesa. $3^{\text {a }}$ ed. Rio de Janeiro: Nova Fronteira, 1999.

FERREIRA, Durval. Negócio juídico condicional. Coimbra: Almedina, 1998.

FERREIRA, José do Valle. Subsídio para o estudo das nulidades. Revista dos Tribunais. São Paulo: Revista dos Tribunais, vol. 53, n. 341, mar./1964.

FERREIRA, Tarlei Lemos. Deserdação por falta de vínculo afetivo e de boa-fé familiar. Revista Síntese de Direito de Família. São Paulo: IOB, vol. 86, out.-nov./2014.

FERREIRA, Waldemar. O "trust" anglo-americano e o "fideicomisso" latino-americano. Revista da Faculdade de Direito, Universidade de São Paulo, 51, pp. 182-202. Disponível em: https://www.revistas.usp.br/rfdusp/article/view/66250. Acessado em 3.12.2019.

FONSECA, Tito Prates da. Sucessão Testamentária. São Paulo: Saraiva, 1928.

FRAGA, Affonso. Breve estudo das disposições modais em suas atinências com as condicionais. Revista dos Tribunais. São Paulo: Revista dos Tribunais, vol. 121.

FRANÇA, Rubens Limongi. O conceito de morte, diante do direito ao transplante e do direito hereditário. Revista da Academia Brasileira de Letras Jurídicas. Rio de Janeiro: Academia Brasileira de Letras Jurídicas, nº 8, 1995.

FURTADO, Paulo. Juízo arbitral. $2^{a}$ ed. Salvador: Nova Alvorada, 1995. 
GIORGIS, José Carlos Teixeira. A justa causa no novo testamento. In: DELGADO, Mário Luiz; ALVES, Jones Figueirêdo (coord.). Questões controvertidas no novo Código Civil. Vol. 2. São Paulo: Método, 2004.

GODOY, Claudio Luiz Bueno de. Dos herdeiros necessários e da gravação da legítima no novo Código Civil. In: NANNI, Giovanni Ettore (coord.). Temas relevantes do direito civil contemporâneo: reflexões sobre os cinco anos do Código Civil. São Paulo: Atlas, 2008.

GOMES, Orlando. Sucessões. 16a ed. rev. e atual. por Mario Roberto Carvalho de Faria. Rio de Janeiro: Forense, 2015.

Introdução ao direito civil. $19^{\mathrm{a}}$ ed. Rio de Janeiro: Forense, 2009.

“Cláusula cominatória em testamento". In: Novas questões de direito civil. $2^{\mathrm{a}}$ ed.

São Paulo: Saraiva, 1988.

GOZZO, Débora; VENOSA, Silvio de Salvo. In: ALVIM, Arruda; ALVIM, Thereza. Comentários ao Código Civil brasileiro. Vol. XVI. Rio de Janeiro: Forense, 2004.

GUIMARÃES, Maria de Nazareth Lobato. Testamento e autonomia. Revista de direito e de estudos sociais. Coimbra: Centro de Direito Comparado da Faculdade de Direito, ano XVIII, $\mathrm{n}^{\text {os }} 1-4,1972$.

Da condição nos testamentos: impossibilidade e ilicitude. Dissertação de licenciatura em Ciências Jurídicas apresentada à Faculdade de Direito da Universidade de Coimbra. [S.l.: s.n.], 1942.

HENRIQUE, Brás. "Vende-se Portinari por uma pechincha". O Estado de São Paulo. Disponível em: < http://brasil.estadao.com.br/noticias/geral,vende-se-portinari-por-umapechincha,393350>. Acessado em 29.4.2018.

HIRONAKA, Giselda Maria Fernandes Novaes. Morrer e suceder: passado e presente da transmissão sucessória concorrente. $2^{\mathrm{a}}$ ed. São Paulo: Revista dos Tribunais, 2014.

In: AZEVEDO, Antônio Junqueira de. Comentários ao Código Civil. Vol. 20. São Paulo: Saraiva, 2003.

Ação de rompimento de testamento público. Revista Brasileira de Direito Civil RBDCivil. Belo Horizonte: Fórum, vol. 17, jul.-set./2018, pp. 171-197.

Famílias paralelas. Revista da Faculdade de Direito, Universidade de São Paulo, 108, 2013, pp. 199-219. Disponível em http://www.revistas.usp.br/rfdusp/article/view/67983. Acessado em 22.11.2018.

In: CAHALI, Francisco José; HIRONAKA, Giselda Maria Fernandes Novaes. Direito das sucessões. $5^{\text {a }}$ ed. São Paulo: Editora Revista dos Tribunais, 2014.

HIRONAKA, Giselda Maria Fernandes Novaes; TARTUCE, Flávio. Planejamento sucessório: conceito, mencanismos e limitações. Revista Brasileira de Direito Civil - RBDCivil. Belo Horizonte: Fórum, vol. 21, jul.-set./2019, pp. 87-109. 
HIRSCH, Adam Jay. American History of Inheritance Law. Oxford International Encyclopedia of Legal History. Stanley N. Katz ed. 2009. FSU College of Law. Public Law Research Paper No. 258. Disponível em: https://ssrn.com/abstract=982428>. Acessado em 19.11.2019.

Instituto Brasileiro de Direito de Família, "Anteprojeto de lei para reforma do direito das sucessões". $\quad$ Disponível em: <http://ibdfam.org.br/assets/upload/anteprojeto_sucessoes/anteprojeto_sucessoes.pdf $>$. Acessado em 3.5.2018.

JURISPRUDÊNCIA brasileira. Testamento. № 81. Curitiba: Juruá, 1983.

KENNEDY, Gerrick D. “Adam 'MCA'Yauch's will forbids use of Beastie Boys' music in ads". Los Angeles Times. Disponível em: <http://articles.latimes.com/2012/aug/10/entertainment/laet-ms-adam-yauch-ads-beastie-boys-20120810>. Acessado em 29.4.2018.

KELLY, Daniel B. Restricting Testamentary Freedom: Ex Ante Versus Ex Post Justifications, 82. Fordham L. Rev. 1125 (2013). P. 1.171. Disponível em: <https://scholarship.law.nd.edu/law_faculty_scholarship/950>. Acessado em 12.11.2019.

KOLOKOSSIAN, Garbis. What are the strangest will requests ever made? Publicado em 13.3.2018. Disponível em: <https://www.contestingwills.com.au/document-366/what-are-thestrangest-will-requests-ever-made $>$, acessado em 18.7.2019.

LACERDA, Paulo de. Manual do Código Civil brasileiro. Vol. XIX. Rio de Janeiro: Jacinto Ribeito dos Santos Editor, 1917.

LAMEK, P. S. A.. "In Re Lysaght: Hill v. The Royal College of Surgeons, [1965] 3 W.L.R. 391". Osgoode Hall Law Journal, 4.1, 1966. Disponível em: <https://digitalcommons.osgoode.yorku.ca/cgi/viewcontent.cgi?referer=https://www.google.c $\mathrm{om} / \&$ httpsredir $=1 \&$ article $=2418 \&$ context $=$ ohlj $>$. Acessado em 2.4.2019.

LARENZ, Karl. Derecho civil: parte general. Madrid: Editorial Revista de Derecho Privado, 1978.

LEITE, Eduardo de Oliveira. In: TEIXEIRA, Sálvio de Figueiredo. Comentários ao novo Código Civil. Vol. XXI. Rio de Janeiro: Forense, 2003.

LIMA, Pires de; VARELA, Antunes. Código Civil anotado. Vol. VI. Coimbra: Coimbra Editora, 1998.

LIMA JÚNIOR, Bruno de Mendonça. Nulidade de testamento - Bens deixados a entidade com sede no estrangeiro - Condição impossível e ilícita - Ação dos herdeiros. Revista dos Tribunais. São Paulo: Revista dos Tribunais, vol. 621, jul./1987.

LÔBO, Paulo. Sucessões. São Paulo: Saraiva, 2013.

LOPES, Miguel Maria de Serpa. Curso de Direito Civil. Vol. I. $8^{\mathrm{a}}$ ed. Rio de Janeiro: Freitas Bastos, 1996.

LUDWIG, Marcos de Campos. Usos e costumes no processo obrigacional. São Paulo: Revista dos Tribunais, 2005. 
MADALENO, Rolf. Testamentos inválidos e ineficazes: revogação, rompimento, caducidade, anulabilidade e nulidade. In: HIRONAKA, Giselda Maria Fernandes Novaes; PEREIRA, Rodrigo da Cunha (org.). Direito das Sucessões e o Novo Código Civil. Vol. 1. $1^{\mathrm{a}}$ ed. Belo Horizonte: Del Rey, 2004, pp. 251-305.

MAIA, Paulo Carneiro. Substituição fideicomissária. São Paulo: Revista dos Tribunais, 1967.

MALUF, Carlos Alberto Dabus. Cláusula de inalienabilidade, incomunicabilidade $e$ impenhorabilidade. $4^{\mathrm{a}}$ ed. São Paulo: Revista dos Tribunais, 2006.

MARINO, Francisco Paulo de Crescenzo. Interpretação do negócio jurídico. São Paulo: Saraiva, 2011.

MARTINS, Pedro A. Batista. Arbitragem no direito societário. São Paulo: Quartier Latin, 2012.

. "Aspectos controvertidos do compromisso". In: MARTINS, Pedro A. Batista; LEMES, Selma M. Ferreira; Carmona, Carlos Alberto. Aspectos fundamentais da lei de arbitragem. Rio de Janeiro: Forense, 1999.

MARTINS-COSTA, Fernanda Mynarski. Condição suspensiva: funções, estrutura e regime jurídico. São Paulo: Almedina.

MARTINS-COSTA, Judith Hofmeister. "Teoria da causa em perspectiva comparativista: a causa no sistema civil francês e no sistema civil brasileiro". AJURIS. Porto Alegre: AJURIS, 1989.

Os direitos fundamentais e a opção culturalista do novo Código Civil. In: SARLET, Ingo Wolfgang (org.). Constituição, direitos fundamentais e o direito privado. Porto Alegre: Livraria do Advogado, 2003.

. O direito sucessório na Constituição: a fundamentalidade do direito de herança. Revista do Advogado. São Paulo: AASP, nº 112, 2011, p. 86.

Pons, 2015.

. A boa-fé no direito privado: critérios para a sua aplicação. São Paulo: Marcial

MAURO, Giovanni di. La clausola arbitrale testamentaria. Giustizia civile.com. Vol. 6. 2017.

Disponível

em:

<https://www.notaioricciardi.it/UFFICIO/Successioni_Donazioni/clausola\%20arbitrale\%20te

stamentaria\%20(giust.civ.).pdf>. Acessado em 30.1.2018.

MAXIMILIANO, Carlos. Direito das Sucessões. Vol. II. $3^{\text {a }}$ ed. Rio de Janeiro: Freitas Bastos, 1952.

MELLO, Marcos Bernardes de. Teoria do fato jurídico: plano da existência. $18^{\mathrm{a}}$ ed. São Paulo: Saraiva, 2012.

MENEZES, Joyceane Bezerra de; LOPES, Ana Beatriz Pimentel. A sucessão testamentária da pessoa com deficiência intelectual e/ou psíquica. In: TEIXEIRA, Daniele Chaves (coord.). Arquitetura do planejamento sucessório. Belo Horizonte: Fórum, 2019. 
MIRANDA, Darcy Arruda. Anotações ao Código Civil brasileiro. Vol. 3. $4^{\mathrm{a}}$ ed. São Paulo: Saraiva, 1995.

MONTEIRO, Lucas Rosa. A justa causa nas cláusulas de inalienabilidade, incomunicabilidade e impenhorabilidade sobre os bens da legítima. Dissertação (Mestrado em Direito Civil). Faculdade de Direito, Universidade de São Paulo, São Paulo, 2018.

MONTEIRO, Washington de Barros. Curso de Direito Civil: direito das sucessões. Vol. VI. $37^{\mathrm{a}}$ ed. São Paulo: Editora Saraiva, 2009.

MONTEIRO FILHO, Carlos Edison do Rêgo. A proibição dos pactos sucessórios: releitura funcional de uma antiga regra. Revista de Direito Privado. São Paulo: Revista dos Tribunais, vol. 72, 2016.

MORAES, Antão de. "Testamento cerrado. Decisão que manda cumprir - Se faz coisa julgada quanto às formalidades extrínsecas - Inobservância dessas formalidades - Ação para anulá-lo com fundamento no art. 1.719, n. III do Código Civil (Legado à concubina) - Prazo prescricional - Presunção do concubinato - Caso de nulidade do legado". Revista dos Tribunais. São Paulo: Revista dos Tribunais, vol. 237, 1955.

MORAES, Rodrigo. Os direitos morais do autor: repersonalizando o direito autoral. Rio de Janeiro: Lumen Juris, 2008. Disponível em: $<$ http://www.rodrigomoraes.com.br/arquivos/downloads/Os_Direitos_Morais_do_Autor__ R odrigo_Moraes.pdf $>$. Acessado em 29.4.2018.

MOREIRA, Adilson José. O que é discriminação? Belo Horizonte: Letramento, 2017.

MOREIRA, José Carlos Barbosa. Invalidade e ineficácia do negócio jurídico. Revista de Direito Privado. São Paulo: Revista dos Tribunais, vol. 15, jul.-set./2003.

MUNIZ, Polyana Stocco. De "além do princípio de prazer" ao "além do princípio de desempenho": ressonâncias da teoria das pulsões no pensamento de Herbert Marcuse. Dissertação (Mestrado em Psicologia). Instituto de Psicologia, Universidade de São Paulo, São Paulo, 2010.

NANNI, Giovanni Ettore. Direito das sucessões: noções e princípio fundamentais. In: VENOSA, Sílvio de Salvo; GAGLIARDI, Rafael Villar; NASSER, Paulo Magalhães (coord.). 10 anos do Código Civil: desafios e perspectivas. São Paulo: Atlas, 2012.

NEVARES, Ana Luiza Maia. Função promocional do testamento. Rio de Janeiro: Renovar, 2009.

As cláusulas de inalienabilidade, impenhorabilidade e incomunicabilidade sob a ótica civil-constitucional. Revista Trimestral de Direito Civil. São Paulo: Padma, vol. 5, 2001.

Perspectivas para o planejamento sucessório. In: TEIXEIRA, Daniele Chaves (coord.). Arquitetura do planejamento sucessório. Belo Horizonte: Forum, 2019.

NITSCHKE, Guilherme Carneiro Monteiro. "Integração" de lacunas contratuais: em busca de um método. Tese (Doutorado em Direito Civil), Faculdade de Direito, Universidade de São Paulo, São Paulo, 2018. 
NONATO, Orosimbo. Estudos sobre sucessão testamentária. Vol. II. Rio de Janeiro: Forense, 1957.

Estudos sobre sucessão testamentária. Vol. III. Rio de Janeiro: Forense, 1957.

NÚMERO de testamentos lavrados cresce $42 \%$ nos últimos cinco anos. Migalhas. Publicado em 20.10.2017. Disponível em <https://www.migalhas.com.br/Quentes/17,MI267466,51045Numero+de+testamentos+lavrados+cresce+42+nos+ultimos+cinco+anos $>$. Acessado em 16.12.2019.

OLIVEIRA, Arthur Vasco Itabaiana de. Tratado de direito das sucessões. Vol. II. Rio de Janeiro: Max Limonad, 1952.

do Brasil, 1918.

Elementos de direito das sucessões. Rio de Janeiro: Officinas Graphicas do Jornal

OLIVEIRA, Eduardo Ribeiro de. In: TEIXEIRA, Sálvio de Figueiredo (coord.). Comentários ao novo Código Civil. Vol. II. Rio de Janeiro: Forense, 2008.

OLIVEIRA, James Eduardo. Código Civil anotado e comentado: doutrina e jurisprudência. Rio de Janeiro: Forense, 2010.

OLIVEIRA, Guilherme Freire Falcão de. Testamento: apontamentos. Coimbra: Reproset, [199?].

OTERO, Marcelo Truzzi. Justa causa testamentária: inalienabilidade, impenhorabilidade e incomunicabilidade sobre a legítima do herdeiro necessário. Porto Alegre: Livraria do Advogado, 2012.

PACHECO, José da Silva. Inventários e partilhas. 19ª ed. Rio de Janeiro: Forense, 2008.

PADOVANI, Fabio. Testamento e arbitrato. Rassegna di Diritto Civile. Vol. 1. Napoli. 2012.

PEREIRA, Caio Mário da Silva. A morte e a sua repercussão na vida negocial. Revista da Academia Brasileira de Letras Jurídicas. Rio de Janeiro: Academia Brasileira de Letras Jurídicas, v. 10, n. 9, 1996.

Instituições de Direito Civil. Vol. VI. 23ª ed. Rio de Janeiro: Forense, 2016.

Instituições de direito civil. Vol. I. 26 a ed. Rio de Janeiro: Forense, 2013.

Comentários ao Código Civil de 2002. Vol. I. Rio de Janeiro: GZ Editora, 2017.

PEREIRA, Jane Reis Gonçalves. Apontamentos sobre a aplicação das normas de direito fundamental nas relações jurídicas entre particulares. In: BARROSO, Luís Roberto (org.). A nova interpretação constitucional: ponderação, direitos fundamentais e relações privadas. $2^{\mathrm{a}}$ ed. Rio de Janeiro: Renovar, 2006.

PEREIRA, Lafayette Rodrigues. Instituição de legado em benefício de fundação a ser constituída - Derrogação das leis de mão morta - Quando o testamenteiro é nomeado inventariante. Revista Forense. Belo Horizonte: Imprensa Oficial do Estado de Minas Gerais, v. IX, 1908. 
PEREIRA, Rodrigo da Cunha. Dicionário de direito de família e sucessões ilustrado. São Paulo: Saraiva, 2015.

PERLINGIERI, Giovanni. Negozio illecito e negozio illegale: una incerta distinzione sul piano degli effetti. Napoli: Edizioni Schientifiche Italiane, 2003.

PERLINGIERI, Pietro. Perfis do direito civil. $3^{\mathrm{a}}$ ed. Rio de Janeiro: Renovar, 2002.

PINHEIRO, Jorge Duarte. O direito das sucessões contemporâneo. Lisboa: AAFDL, 2013.

PINTO, Carlos Alberto da Mota. Teoria Geral do Direito Civil. $4^{\mathrm{a}}$ ed. atual. por António Pinto Monteiro e Paulo Mota Pinto. Coimbra: Coimbra Editora, 2012.

PINTO, Paulo Mota. Autonomia privada e discriminação - algumas notas. In: Tribunal Constitucional. Estudos em homenagem ao Conselheiro José Manuel Cardoso da Costa. Coimbra: Coimbra Editora, 2005.

PLANIOL, Marcel, RIPERT, Georges. Droit civil français. Tomo 5. Paris: Librairie Générale de droit \& de jurisprudence, 1933.

POLETTO, Carlos Eduardo Minozzo. Indignidade sucessória e deserdação. São Paulo: Saraiva, 2013.

PONTES DE MIRANDA, Francisco Cavalcanti. Tratado dos testamentos. Vol. I. Leme: BH Editora e Distribuidora, 2005.

. Tratado dos testamentos. Vol. III. Leme: BH Editora, 2005.

. Tratado de direito privado. Tomo IV. Atualizado por Marcos Bernardes de Mello, Marcos Ehrhardt Jr. São Paulo: Revista dos Tribunais, 2012.

. Tratado de direito privado. Tomo LVI. Atualizado por Giselda Maria Fernandes Novaes Hironaka, Paulo Lôbo. São Paulo: Revista dos Tribunais, 2012.

. Tratado de direito privado. Tomo LVII. Atualizado por Giselda Maria Fernandes Novaes Hironaka, Paulo Lôbo. São Paulo: Revista dos Tribunais, 2012.

. Tratado de direito privado. Tomo LVIII. Atualizado por Giselda Maria Fernandes Novaes Hironaka, Paulo Lôbo. São Paulo: Revista dos Tribunais, 2012.

. Tratado de direito privado. Tomo LX. Atualizado por Giselda Maria Fernandes Novaes Hironaka, Paulo Lôbo. São Paulo: Revista dos Tribunais, 2012.

2008.

. Comentários ao Código de Processo Civil. Tomo XVI. Rio de Janeiro: Forense,

POTHIER, R. J., BUGNET, M. Ouevres de Pothier annotees et mises en correlation avec le code civil et la legislation actuelle. Vol. 08. Paris: Henri Plon, 1861.

PRATA, Ana. A tutela constitucional da autonomia privada. Coimbra: Almedina, 2016. 
PRETTO, Cristiano. Redescoberta da personalidade e testamento. Revista IBDFAM Família e Sucessões. Belo Horizonte: IBDFAM, vol. 18, 2016.

RAIZER, Ludwig. O futuro do direito privado. Revista da Procuradoria-Geral do Estado do Rio Grande do Sul. Porto Alegre: Instituto de Informática Jurídica, v. 9, n. 25, 1979.

RAMOS, André Luiz Arnt; CATALAN, Marcos Jorge. O eterno retorno: a que(m) serve o modelo brasileiro de direito sucessório?. Civilistica.com. Rio de Janeiro, a. 8, n. 2, 2019. Disponível em: <http://civilistica.com/o-eterno-retorno/>. Acessado em 3.12.2019.

RAÓ, Vicente. Ato jurídico. $4^{\mathrm{a}}$ ed. São Paulo: Editora Revista dos Tribunais, 1999.

RIOS, Roger Raupp; LEIVAS, Paulo Gilberto Cogo; SCHÄFER, Gilberto. "Direito da antidiscriminação e direitos de minorias: perspectivas e modelos de proteção individual e coletivo". Revista Direitos Fundamentais \& Democracia, v. 22, n. 1, jan.-abr./2017.

RIZZARDO, Arnaldo. Direito das sucessões. 11ª ed. Rio de Janeiro: Forense, 2019.

ROCCHI, Rosanne T. Testamentary Freedom and Policy Constraints. Publicado em março de 2016. Disponível em: <https://www.millerthomson.com/en/publications/communiques-andupdates/wealth-matters/march-2016-wealth-matters/testamentary-freedom-and-policyconstraints/>. Acessado em 8.11.2019.

RODRIGUES, Cláudia. As leis testamentárias de 1765 e 1769 no contexto das "reformas pombalinas" no mundo luso-brasileiro. XIII Encontro de História Anpuh-Rio. Disponível em <http://www.encontro2008.rj.anpuh.org/resources/content/anais/1212772170_ARQUIVO_As leistestamentariasde1765e1769-CLAUDIARODRIGUES.pdf>. Acessado em 1.7.2019.

RODRIGUES, Silvio. Direito civil. Vol. I. 34ª ed. São Paulo: Saraiva, 2007. Direito civil. Vol. 7. 25 ed. São Paulo: Saraiva, 2002.

"Testamentos. Requisitos de validade. Possibilidade de o testador indicar os bens que comporão a legítima dos herdeiros necessários. Legalidade da cláusula que comina pena aos herdeiros que se rebelarem contra o testamento. Fideicomisso. Proibição de sua instituição além de um grau. Possibilidade de indicar desde loho substituto aos fideicomissários. Legalidade da cumulação da substituição vulgar e fideicomissária. Possibilidade de os fideicomissários serem escolhidos pela fiduciária, dentro de certo grupo apontado pelo testador”. In: Direito civil aplicado. Vol. 1. São Paulo: Saraiva, 1981.

"Testamento. Cláusula testamentária deixando administração de legítima dos bens à viúva. Invalidade da disposição. Limites legais à clausulação de legítima. Interpretação do art. 1.723 do Código Civil. Mandato tácito. Conceito. Obrigações do mandatário, inclusive a de prestar contas. Liberalidade. Quando feita com bens do espólio imputam-se no quinhão do inventariante". In: Direito Civil aplicado. Vol. 6. São Paulo: Saraiva, 1994.

Dos vícios do consentimento. $2^{\mathrm{a}}$ ed. São Paulo: Saraiva, 1982.

ROQUE, Sebastião José. Direito das sucessões. São Paulo: Ícone, 1995. 
ROSA, Carla Müller da. Os motivos enquanto elemento juridicamente relevante. In: BENETTI, Giovana (coord.) et al. Direito, cultura, método: leituras da obra de Judith Martins-Costa. Rio de Janeiro: GZ Editora, 2019, pp. 718-738.

ROSÉS, Fernando Carol. Libertad para testar y libertad de testar. La eficacia inter privados del principio de no discriminación. In: MOTA, Helena; GUIMARÃES, Maria Raquel (coord.). Autonomia e heteronomia no direito da família e no direito das sucessões. Coimbra: Almedina, 2016.

SANTOS, J. M. de Carvalho. Código Civil brasileiro interpretado. Vol. III. $14^{\mathrm{a}}$ ed. Rio de Janeiro: Freitas Bastos, 1991.

Bastos, 1986.

Código Civil brasileiro interpretado. Vol. XXIII. $11^{\text {a }}$ ed. Rio de Janeiro: Freitas

. Código Civil brasileiro interpretado. Vol. XXIV. $2^{\mathrm{a}}$ ed. Rio de Janeiro: Freitas Bastos, 1938.

SCHREIBER, Anderson. Manual de direito civil contemporâneo. São Paulo: Saraiva, 2018.

. In: SCHREIBER, Anderson; TARTUCE, Flavio; SIMÃO, José Fernando et al. Código Civil comentado: doutrina e jurisprudência. Rio de Janeiro: Forense, 2019.

SILVA, Joel Belchior da. A discriminação e o direito civil: breves notas sobre as consequências jurídicas da discriminação. Jurismat, Portimão, 2017, n 10, p. 126.

SILVA, Jorge Cesa Ferreira da. A antidiscriminação no direito contratual brasileiro: possibilidades e limites do acolhimento de um princípio. Tese (Doutorado em Direito Civil), Faculdade de Direito, Universidade de São Paulo, São Paulo, 2018.

SILVA, Regina Célia de Almeida da; et al. Testamento. Rio de Janeiro: Esplanada: ADCOAS, 1993.

SIMÃO, José Fernando. É possível converter os bens da legítima em dinheiro? In: PEREIRA, Rodrigo da Cunha; DIAS, Maria Berenice (coord.). Famílias e sucessões: polêmicas, tendências e inovações. Belo Horizonte: IBDFAM, 2018.

In: LAGRASTE NETO, Caetano; SIMÃO, José Fernando (coord.). Dicionário de direito de família. Vol. 1. São Paulo: Atlas, 2015.

O testamento magistral: uma nova figura criada em Guaxupé (parte 1). Conjur. Publicado em 5.8.2018. Disponível em: <https://www.conjur.com.br/2018-ago-05/processofamiliar-testamento-magistral-figura-criada-guaxupe-parte>. Acessado em 17.4.2019.

O testamento magistral: uma nova figura criada em Guaxupé (parte 2). Conjur. Publicado em 11.8.2018. Disponível em <https://www.conjur.com.br/2018-ago-12/processofamiliar-testamento-magistral-figura-criada-guaxupe-parte>. Acessado em 17.4.2019.

In: SCHREIBER, Anderson; TARTUCE, Flavio; SIMÃO, José Fernando et al. Código Civil comentado: doutrina e jurisprudência. Rio de Janeiro: Forense, 2019. 
SNEDDON, Karen J. The Will as Personal Narrative (2013). Elder Law Journal, Vol. 20, 2013. Disponível em: 〈https://ssrn.com/abstract=2354609>. Acessado em 12.12.2019.

SOUZA, Eduardo Nunes de. Teoria Geral das Invalidades do Negócio Jurídico: nulidades e anulabilidades no Direito Civil contemporâneo. São Paulo: Almedina, 2017.

SOUZA, José Ulpiano Pinto de. Das cláusulas restrictivas da propriedade: inalienabilidade, impenhorabilidade incommunicabilidade, conversão e administração. São Paulo: Escolas Prof. Salesianas, 1910.

STF nega Habeas Corpus a editor de livros condenado por racismo contra judeus". Publicado em17.9.2003. Disponível $<$ www.stf.jus.br/portal/cms/verNoticiaDetalhe.asp?idConteudo=61291>. Acessado em 5.4.2019.

STJ: Nancy valida testamento que contou apenas com impressão digital da testadora. Migalhas, publicado em 11.12.2019, disponível em: <https://www.migalhas.com.br/Quentes/17,MI316917,81042-

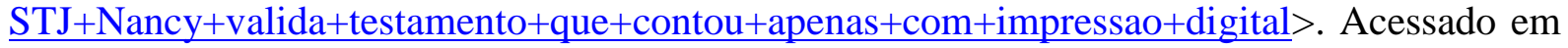
11.12.2019.

SWENNEN, Frederik; BARBAIX, Renate. Ethical Wills - A Continental Law Perspective. Oñati Socio-Legal Series, Vol. 4, No. 2, 2014. Disponível em: <https://ssrn.com/abstract=2431115 >. Acessado em 22.7.2019.

TARTUCE, Flávio. O Estatuto da Pessoa com Deficiência e a capacidade testamentária ativa. Revista Pensamento Jurídico. São Paulo. Vol. 10. 2016.

Direito civil. Vol. 6. 11 a ed. Rio de Janeiro: Forense, 2018.

TATSCH, Arno Gaspar. Anotações quanto ao testamento. Revista Forense. Rio de Janeiro: Forense, vol. 302, abr.-jun./1988, pp. 69-83.

TEIXEIRA, Daniele Chaves. Planejamento sucessório: pressupostos e limites. Belo Horizonte: Fórum, 2017.

TELLES, Inocêncio Galvão. Sucessão testamentária. Coimbra: Coimbra Editora, 2006.

Direito das sucessões: noções fundamentais. $2^{\mathrm{a}}$ ed. Lisboa: Centro de Estudos de Direito Civil da Faculdade de Direito da Universidade de Lisboa, 1973.

TEPEDINO, Gustavo; SCHREIBER, Anderson. A discriminação no direito brasileiro (breve incursão pelo Direito Internacional Privado). In: PEREIRA, Antônio Celso Alves; MELLO, Celso Renato Duvivier de Albuquerque (coord.). Estudos em homenagem a Carlos Alberto Menezes Direito. Rio de Janeiro: Renovar, 2003.

Minorias no direito civil brasileiro. Revista Trimestral de Direito Civil. Rio de Janeiro: Editora Padma, v. 10, abr.-jun./2002.

TEPEDINO, Gustavo; BARBOZA, Heloisa Helena; MORAES, Maria Celina Bodin de. Código civil interpretado conforme a constituição da república, vol. IV. Rio de Janeiro: Renovar, 2014. 
THE Second-Best Bed. The Shakespeare Birthplace Trust. Disponível em: $<$ https://www.shakespeare.org.uk/about-us/>. Acessado em 16.12.2019).

TOLEDO, Maria Beatriz de Miranda. Captação dolosa da vontade do testador. Trabalho de conclusão de curso (Bacharelado em Direito). Ibmec, Rio de Janeiro, 2014.

TRUSTS and estates - Electronic wills - Michigan Court of Appeals holds electronic document to be valid will under harmless error rule - In re Estate of Horton, No. 339737 (Mich. Ct. App. July 17, 2018) (per curiam). 132 Harvard Law Review 2082. Publicado em 10.5.2019. Disponível em: <https://harvardlawreview.org/2019/05/in-re-estate-of-horton/>. Acessado em 19.11.2019.

UBILLOS, Juan María Bilbao, Proibição de discriminação e relações privadas. In: SOUZA NETO, Cláudio Pereira de; SARMENTO, Daniel (coord.). A constitucionalização do direito: fundamentos teóricos e aplicações específicas. Rio de Janeiro: Lumen Juris, 2007.

VALVERDE, Iracema A.; ALMEIDA, Patrícia de Castro; GONÇALVES, Angela Clara F. (org.). Testamento. $2^{\mathrm{a}}$ ed. Rio de Janeiro: Esplanada, 2003.

VARELA, João de Matos Antunes. Ineficácia do testamento e vontade conjectural do testador. Coimbra: Coimbra Editora, 1950.

VENOSA, Silvio de Salvo. Inalienabilidade, impenhorabilidade e incomunicabilidade. Revista do Advogado. São Paulo: AASP, nº 91, 2007.

VELOSO, Zeno. Invalidade do negócio jurídico: nulidade e anulabilidade. $2^{\mathrm{a}}$ ed. Belo Horizonte: Del Rey, 2005.

. Condição, termo e encargo. São Paulo: Malheiros, 1997.

In: AZEVEDO, Antônio Junqueira de. Comentários ao Código Civil. Vol. 21.

São Paulo: Saraiva, 2003.

. Testamentos. $2^{\mathrm{a}}$ ed. Belém: CEJUP, 1993.

XAVIER, Rita Lobo. Planejamento sucessório e transmissão do patrimônio à margem do direito das sucessões. Porto: Universidade Católica do Porto Editora, 2016. 